NBER WORKING PAPER SERIES

\title{
BANK MERGERS AND CRIME: \\ THE REAL AND SOCIAL EFFECTS OF CREDIT MARKET COMPETITION
}

\author{
Mark J. Garmaise \\ Tobias J. Moskowitz \\ Working Paper 11006 \\ http://www.nber.org/papers/w11006 \\ NATIONAL BUREAU OF ECONOMIC RESEARCH \\ 1050 Massachusetts Avenue \\ Cambridge, MA 02138 \\ December 2004
}

\begin{abstract}
We have benefitted from the suggestions and comments of Tony Bernardo, Marianne Bertrand, Phillip Bond, Doug Diamond, Mark Duggan, Eugene Fama, Kenneth French, Jonathan Guryan, Erik Hurst, Matthias Kahl, Anil Kashyap, Steven Levitt, Atif Mian, Sendhil Mullainathan, Canice Prendergast, Raghu Rajan, Tano Santos, Per Stromberg, Luigi Zingales, and seminar participants at the University of Chicago Graduate School of Business, NYU, Wharton, UCLA, University of Washington, and Dartmouth College. Special thanks to Michael Arabe, John Edkins, and Peggy McNamara as well as COMPS.com for providing the U.S. commercial real estate data, to Bob Figlio, Dave Ingeneri, and CAP Index, Inc. for providing the crime data, to F.W. Dodge Division of the McGraw-Hill Companies, Inc. for providing the construction data, to John J. Donohue III and Steven Levitt for providing abortion rate and imprisonment rate data, and to Phil Strahan for providing state bank branching dates. Moskowitz thanks the Center for Research in Security Prices and the James S. Kemper Foundation Research Fund for financial support. The views expressed herein are those of the author(s) and do not necessarily reflect the views of the National Bureau of Economic Research.
\end{abstract}

(C) 2004 by Mark J. Garmaise and Tobias J. Moskowitz. All rights reserved. Short sections of text, not to exceed two paragraphs, may be quoted without explicit permission provided that full credit, including () notice, is given to the source. 
Bank Mergers and Crime: The Real and Social Effects of Credit Market Competition Mark J. Garmaise and Tobias J. Moskowitz

NBER Working Paper No. 11006

December 2004

JEL No. G3

\begin{abstract}
Using a unique sample of commercial loans and mergers between large banks, we provide microlevel (within-county) evidence linking credit conditions to economic development and find a spillover effect on crime. Neighborhoods that experienced more bank mergers are subjected to higher interest rates, diminished local construction, lower prices, an influx of poorer households, and higher property crime in subsequent years. The elasticity of property crime with respect to merger-induced banking concentration is 0.18 . We show that these results are not likely due to reverse causation, and confirm the central findings using state branching deregulation to instrument for bank competition.
\end{abstract}

Mark J. Garmaise

Anderson School

UCLA

mark.garmaise@anderson.ucla.edu

Tobias J. Moskowitz

Graduate School of Business

University of Chicago

1101 East 58th Street

Chicago, IL 60637

and NBER

tobias.moskowitz@gsb.uchicago.edu 
We examine the real and social impact of local credit competition by documenting a link between the competitiveness of the local banking market, credit conditions, urban development, and crime. Several recent studies (Peek and Rosengren (2000), Cetorelli and Gambera (2001), Klein, Peek, and Rosengren (2002), and Burgess and Pande (2003)) tie credit market imperfections to diminished real economic activity and growth. Other studies connect the economic environment to property crime (Freeman (1999), Levitt (2001), Raphael and Winter-Ebmer (2001), and Nilsson (2004)). It is reasonable to hypothesize, therefore, that reductions in bank competition may lead to economic decline and, subsequently, increases in property crime. We empirically investigate the effects of bank consolidation and increased market power on credit availability and real activity using a unique sample of commercial loans and mergers between large banks in the 1990's. We provide micro-level evidence that neighborhoods that experienced greater reductions in bank competition due to bank mergers are subjected to future higher interest rates, diminished local construction, lower real estate prices, and an influx of poorer households. We then examine whether these changes impact the social environment by studying subsequent changes in crime rates across neighborhoods, and find an associated increase in property crime. Importantly, these results do not appear to be due to reverse causation since, among other evidence, our large bank mergers are not preceded by or contemporaneously correlated with crime increases or economic declines.

Our empirical strategy employs mergers between banks of at least $\$ 1$ billion in assets to capture plausibly exogenous changes in the competitiveness of local banking markets. We consider only variation at the neighborhood level within counties in banking loan market competitiveness generated by mergers of non-failing large commercial banks. The size, scope, and health of these banks makes it unlikely that economic declines in the local neighborhoods we examine are driving the mergers. We then analyze the local market effects of these mergers on subsequent loan supply, interest rates, property prices, investment activity, economic and demographic variables, and crime. It is worth emphasizing at the outset that we only examine the relation between changes in bank competition through large mergers and changes in economic conditions and crime across neighborhoods. Bank competition cannot explain the aggregate national decline in crime over the last few decades nor differences in the level of crime across regions. Indeed, we control for both the time trend and variation in crime levels across counties in our analysis. This paper merely documents that changes in local credit market competition, which affect changes in local real activity, have interesting spillover effects on social outcomes such as crime.

Local financial development can be paramount to economic growth even in a well-integrated 
financial environment (Guiso, Sapienza, and Zingales (2004)). The market for small commercial real estate loans is localized due to information and agency considerations (Garmaise and Moskowitz $(2003,2004))$. For these reasons, merger-induced changes in the local competitive environment can have sizeable effects. We find that when loan competition declines (via large bank mergers), interest rates charged on loans rise significantly and borrowers receive smaller loans from banks. ${ }^{1}$ These findings also control for bank-specific fixed effects, indicating that the same bank is setting different loan terms in areas with different levels of competition. It is important to note, however, that these mergers lead to short-term distortions in the loan market. In the longer-term, entry of new banks and increased loan supply by existing banks should lead to a restored competitive equilibrium (Berger, Saunders, Scalise, and Udell (1998)). Consistent with this notion, we show that mergers' impact on the local competitive environment lasts about three years, ceasing to have any significant effect on credit or loan terms beyond this time.

It is during this short-term distortion of the local loan market that large banking mergers have substantial real economic implications. We find that commercial real estate development, which is often a marginal investment for banks, and new construction activity fall significantly. In addition, local property prices decline. Examining local demographic and migration data from the census, we then find that unemployment in the area rises, median income drops, and income inequality increases. Moreover, the income of new arrivals into the neighborhood is below that of long-term residents, suggesting an exodus (influx) of higher (lower) income households in response to the local decline in property values.

These changing economic and demographic characteristics provide a plausible channel through which crime may rise. In particular, we find subsequent increases in burglary and, more broadly, property crimes in these areas. There appears to be, however, no significant increase in homicide or other personal crimes, which have a tenuous relation with economic activity. It is a general conclusion of the crime literature that economic decline is linked closely to property crime but loosely, if at all, to personal/violent crime (see Levitt (2001), Raphael and Winter-Ebmer (2001), and Nilsson (2004)). Our results are consistent with bank mergers leading to economic deterioration, which in turn results in more property crime, but has no definite effect on violent crime. We find that the elasticity of property crime risk with respect to merger-induced bank concentration is 0.18. The crime literature reports elasticities of crime with respect to direct economic variables such as wages and unemployment in the range of 0.6 to 0.9, (Grogger (1998), Rickman and Witt (2003)),

\footnotetext{
${ }^{1}$ Although several empirical studies have examined the effects of bank mergers on loan markets, most analyze aggregate market data. An exception is Sapienza (2002), who provides evidence on individual loan contracts.
} 
so the magnitude of the elasticity we find suggests an indirect effect of credit market terms on property crime via economic mechanisms. The effect on crime itself is small, but clearly important to local residents. Applying our results to national crime figures from the FBI's Uniform Crime Reports, the mean decline in banking competitiveness due to mergers from 1992 to 1995 that we document is associated with approximately 24,300 more property crime offenses over the period 1995 to 2000 across the U.S.

We also find that the differential effect of mergers on property crime risks varies across neighborhoods. Areas that already have high banking concentration and low median income are more severely affected by a merger-induced reduction in loan competition. This suggests that the real and social costs of bank mergers can be much higher in fragile neighborhoods.

While we believe that this body of evidence suggests a plausible causal (though indirect) link from bank mergers to crime, a natural alternative theory for these results is reverse causation. In considering the hypothesis that future crime increases are in some way prompting present-day mergers, we first note that commercial real estate loans are only a small part of banks' portfolios and, in any case, the future price effects we find correlated with mergers are small. In addition, we consider only the mergers of non-failing, large (more than $\$ 1$ billion in assets) banks, which almost certainly are not driven by the possibility of future neighborhood-level declines. Nonetheless, we investigate the hypothesis that some unobservable economic variables that affect future crime also motivate present-day bank mergers.

Evidence against this alternative hypothesis is summarized in the following set of results. First, we find that while bank mergers antedate economic deterioration and increases in crime, economic decline and increases in crime are not correlated with either contemporary or future bank mergers. Second, while we employ only non-failing banks for our merger variable, as a robustness test we also compute a change in concentration measure from the mergers of failing banks only, since these are the most likely to be associated with economic declines in the neighborhoods in which they operate. We find, however, that mergers between failing banks do not predict future crime increases. While difficult to reconcile with reverse causation, this finding is consistent with mergers affecting competition, since the removal of a failing bank from the market probably has only a small competitive effect. Third, we also examine changes in the number of non-lending financial institutions such as insurance companies and securities brokers. These institutions, like banks, are affected by the current and past local economic environment, but unlike banks they should have no impact on local credit conditions. Consistent with this, we find no association between 
consolidation of non-lending institutions and future crime, failing to support reverse causation. Finally, when we consider mergers that should not affect the local competitive environment, for example when outsider banks acquire insider banks, such mergers do not predict changes in credit conditions or increases in future crime. This collection of results suggests the reverse causation theory is not very plausible.

Although our analysis focuses on neighborhood variation in economic activity and crime, we also examine county and state level variation that employ additional variables of interest. At the county level, we obtain additional construction and crime statistics and show that increased bank mergers predict reduced construction activity and higher burglary rates, but again do not predict increased homicide rates. At the state level, we also employ another measure of bank competition using variation in state deregulation of bank branching. Branching deregulation had the opposite effect of mergers by improving credit competition. Consistent with this, in years immediately following deregulation of branching restrictions within a state, we find decreases in banking concentration, loan rate reduction, increasing loan sizes, rising property prices, and declining burglary rates, with no effect on homicide. These findings are consistent with our neighborhood-level results and the link between credit conditions, economic activity, and property crime.

Our findings relate to the literature on the real effects of credit market imperfections. ${ }^{2}$ They are also broadly consistent with the literature on finance and development that suggests that a large financial sector is critical for fostering growth. ${ }^{3}$ Complementing this literature, we provide microlevel evidence of neighborhood credit markets within the U.S. having important impacts on local real activity. We further provide novel evidence on spillovers from credit market competitiveness to social outcomes such as crime. More broadly, the potential connection between finance, real activity, and social outcomes is an intriguing area of further study.

The rest of the paper is organized as follows. Section I details the commercial loan data, crime data, construction and census data, and bank merger activity used to examine the real and social effects of financial access. Section II describes the empirical strategy we employ to exogenously

\footnotetext{
${ }^{2}$ In a cross-country comparison, Cetorelli and Gambera (2001) find that concentrated banking industries depress growth. Peek and Rosengren (2000) and Klein, Peek, and Rosengren (2002) show that the declining position of Japanese banks in the 1990's led to significant reductions in construction activity and foreign direct investment in the U.S. Hancock and Wilcox (1997) demonstrate that the capital crunch of the early 1990's significantly reduced both commercial and residential real estate construction and sales. Black and Strahan (2002) and Jayaratne and Strahan (1996) show that new business incorporations and income growth followed U.S. branching deregulation. Burgess and Pande (2003) find evidence that the rural bank branch expansion program in India from 1977 to 1990 lowered rural poverty and increased non-agricultural output.

${ }^{3}$ King and Levine (1993), Rajan and Zingales (1998), and Demirguc-Kunt and Maksimovic (1998) show that financial development is important for real growth across countries and Guiso, Sapienza, and Zingales (2004) find that local financial development is a key determinant of local economic success within Italy.
} 
measure changes in banking competitiveness through large bank mergers. Section III analyzes the impact of a decrease in bank competition (through mergers) on subsequent loan rates and supply, economic and demographic variables, and crime risks. Section IV provides further evidence on the exogeneity of the bank merger variable and tests alternative theories such as reverse causation. Section V conducts county and state level analysis employing state deregulation of bank branching as another instrument for competition. Finally, Section VI concludes the paper.

\section{Data and Summary Statistics}

We briefly describe the variety of data sources used in the paper.

\section{A. Transaction level data from the U.S. commercial real estate market}

Our sample consists of 22,642 commercial real estate transactions drawn from across the U.S. over the period January 1, 1992 to March 30, 1999 from COMPS.com, a leading provider of commercial real estate sales data. COMPS collects data on commercial real estate transactions by contacting buyers, sellers, and brokers, and then confirms their reports with each of these parties. Garmaise and Moskowitz (2003a, 2003b) provide an extensive description of the COMPS database and detailed summary statistics. The data span 11 states: California, Nevada, Oregon, Massachusetts, Maryland, Virginia, Texas, Georgia, New York, Illinois, and Colorado, plus the District of Columbia.

Properties are grouped into three mutually exclusive types: apartments (defined as multi-family dwellings, apartment complexes, condominiums, and townhouses), vacant land, and commercial and industrial buildings. Panel A of Table 1 reports summary statistics on the properties in our sample. The average (median) sale price is $\$ 2.4$ million $(\$ 600,000)$. The majority of transacted properties are relatively small, though values range from $\$ 20,000$ to $\$ 750$ million, and there are only 42 transactions involving REITS (less than 0.2 percent of the sample). Capitalization rates, defined as net income on the property divided by sale price, and property age are also reported. The mean, median, standard deviation, and extreme one percentiles are reported to gauge outliers.

Perhaps the greatest strength of the COMPS database, however, is the detailed information about specific property transactions. In particular, the data are well detailed with regard to property location, identity and location of market participants, and financial structure. For example, COMPS provides eight digit latitude and longitude coordinates of the property's location (accurate to within 10 meters). From these, we construct characteristics of the local market in which each 
property resides. This enables us to match each property with local crime risks as well as local census statistics at as fine a level as the census block group.

\section{A.1 Financial structure and terms}

The COMPS data contain detailed financing information for each property transaction. We focus on the terms of the loan contract, including interest rates, and the size and presence of bank loans. As Panel A of Table 1 indicates, the average loan size as a fraction of sale price is over 75 percent and even the first percentile of properties with loans have at least 20 percent loan-to-value. The data also contain rich detail on loan terms. Of the 12,937 deals involving debt, 8,573 (roughly 2/3) have information about the interest rate charged on those loans. Panel A shows that annualized loan rates average 8.28 percent over the entire sample and rates range from 5 to 11.75 percent per annum. Other details of the loan contract documented are the maturity of the loan, whether the loan rate is floating or fixed, whether amortized and the length of amortization, and whether the loan was subsidized by the Small Business Administration (only 1.3 percent of loans).

Panel B of Table 1 describes the subset of loans that are made by identifiable banks (for some loans the source is not identified and other loans are made by insurance companies, investment banks, or other financial institutions). We identify 769 distinct banks making loans in our sample. Of these, we classify 210 "large banks" as those having at least $\$ 1$ billion in assets. It is the mergers among these large banks that we employ as our instrument for competition. Large banks made 5,092 loans, comprising 60 percent of the total number of loans, but tended to make larger loans on average, comprising more than 74 percent of debt financings on a dollar basis.

\section{B. Bank merger activity}

Since we employ mergers between large banks as an instrument for changes in bank competition in the local area (discussed in detail in the next section), we report summary statistics on bank merger and acquisition activity over our sample period in Panel B of Table 1. Information on bank mergers is obtained from the Commercial Bank Database of the Federal Reserve. Information on bank high holding companies (used to track asset levels and acquisitions) is obtained from the Call Report Database (Reports of Condition and Income data) of the Federal Reserve System, Federal Deposit Insurance Corporation, and the Comptroller of the Currency.

We include only the following types of mergers and acquisitions in our study:

1. Bank mergers (i.e., combinations in which one FDIC certificate is surrendered) between two 
banks each with at least $\$ 1$ billion in assets on the quarter-end preceding the merger. The merger must be classified as "non-failing" 4 and cannot be between two banks owned by the same bank holding company.

2. Bank acquisitions in which a high holding company owning banks with total assets of at least $\$ 1$ billion in assets acquires a bank with at least $\$ 1$ billion in assets. The acquired bank must have been previously owned by a different high holding company or by no holding company. The acquired bank retains its FDIC certificate.

Of the 769 different banks making loans in our sample, 316 were involved in a merger or acquisition at some point during the period 1992 to 1999. Of the 210 large banks in our sample, 80 were involved in mergers and acquisitions that met the two criteria listed above. The large number of mergers and acquisitions over our sample period is critical for our empirical strategy to identify exogenous changes in bank competition. Examples of mergers and acquisitions included and excluded from our study are given in Table A1 of the appendix. An example of the first type of included union is the merger between Wells Fargo and First Interstate Bankcorp in April-June, 1996. The various banks owned by the First Interstate holding company were merged with Wells Fargo, and the acquired banks gave up their FDIC certificates. An example of the second type of included combination is the acquisition of First Chicago by the National Bank of Detroit (NBD Bank). The holding company that had previously owned NBD purchased First Chicago and the name of the holding company was changed to First Chicago NBD Corp. Both NBD Bank and First Chicago retained their separate FDIC certificates. For simplicity, we will henceforth refer to mergers as only those that meet the criteria above. Table A1 also gives examples of mergers involving "failing" banks, mergers between two banks in the same holding company, and mergers involving banks with less than $\$ 1$ billion in assets. These mergers are all excluded, though we will employ them for "placebo" tests and tests of alternative theories later.

We selected our merger inclusion criteria to minimize the possibility that any association we find between bank mergers and subsequent worsening of credit terms, reduction in local real activity, and increase in crime is driven by endogenous factors such as forecasted neighborhood changes. We include only those mergers that are least likely to be driven by concerns over local decline: mergers between very large, non-failing banks. These banks not only comprise a significant fraction of loans in the sample, but are making loans across a wide geographic area both in our sample (across all 12

\footnotetext{
4 "Non-failing" mergers are those not requiring assistance from the FDIC, RTC, NCUA, state, or other regulatory agencies.
} 
states, 38 counties, and 881 zip codes) and more generally across the U.S. From Call Report data we estimate that the average large bank in our sample has $\$ 5.84$ billion in assets and has 16,804 branch offices in 41 states, 949 counties, and 6,644 different zip codes. Given their size and geographic diversity it seems unlikely that local economic conditions of the small neighborhoods (within county) we examine could be driving the mergers between these large institutions. Nevertheless, we will investigate this particular hypothesis in Section IV. Mergers within a bank holding company are excluded because they are unlikely to have significant competitive effects. In section IV we provide evidence that large bank mergers serve as a valid instrument for future bank market competition.

\section{Crime data}

We augment our sample with crime risk data from CAP Index, Inc. CAP Index computes the crime score index for a particular location by combining geographic, economic, and population data with local police, victim, and loss reports. Specifically, data from police reports, the FBI's Uniform Crime Report (UCR), client loss reports, and offender and victim surveys are combined to form a crime score. The combination of crime risk information from several sources allows for a richer and more geographically refined measure of crime than can be provided by the FBI's UCR, for instance. ${ }^{5}$ CAP Index supplies crime scores to businesses looking to relocate or banks seeking automated teller machine locations. We match each property's eight digit latitude and longitude coordinates with the crime score index for those coordinates. Hence, we obtain a property specific crime score, rather than a county average or coarser crime rate. This is particularly useful since we can match crime risks with particular property transactions and therefore particular financing characteristics associated with those transactions. However, we also recognize that crime scores of individual properties will be highly correlated within an area and deal with this issue in our econometric analysis.

The crime scores measure the probability that a certain crime will be committed in a given location relative to national and county levels of crime. For example, a crime score of 1 means that the likelihood of a particular crime being committed is the same in the location as the national (or county) average for that year. Crime scores range from 0.1 to 20. CAP Index scores the seven crimes listed in the FBI's UCR as Part 1 Offenses: homicide, rape, robbery, aggravated assault,

\footnotetext{
${ }^{5}$ For example, UCR data are typically at the county or city level. Hence, a property on the south side of Chicago would have the same crime rate as one downtown, which would have the same score as any city in Cook county. CAP Index scores offer wide variation in crime risks within a city and even within neighborhoods. For example, for the 60610 zip code (downtown Chicago), our data provide 44 different burglary risk scores for the year 2000. While these scores are highly correlated, they provide additional micro-level variation over UCR crime rates.
} 
burglary, larceny, and motor vehicle theft. The first four are classified as "crimes against persons" and the last three as "crimes against property." An index of personal crime and property crime, which are averages of the respective crime scores in those categories, is also reported. We consider two specific crime scores, homicide and burglary, as well as the two general crime indices, personal crimes and property crimes. CAP Index provided crime scores at three points in time: 1990, 1995, and 2000. We examine the changes in crime risk over the two periods before and after 1995 .

Panel $\mathrm{C}$ of Table 1 indicates that crime risks are on average higher than the national average (i.e., greater than 1) in the locations covered by the COMPS database. This is not surprising since COMPS covers commercial markets which are weighted toward larger cities and more metropoli$\tan /$ populated areas. As the table indicates, however, there is substantial variation in crime risks across the property locations covered by COMPS.

We also supplement our analysis with county and state level crime rate data from the FBI's UCR for robustness. As Panel $\mathrm{C}$ of Table 1 indicates, the correlation between the nationally adjusted Cap Index crime score and county level UCR crime rates is fairly high ( 0.37 for homicides and 0.56 for burglaries in 2000). However, the county-adjusted Cap Index scores are virtually uncorrelated with UCR county crime rates, providing finer geographic variation in crime within counties.

\section{Census and construction data}

Finally, we supplement our sample with census statistics on income distribution, median housing value, unemployment, and population at the census tract level and construction data from $F$. $W$. Dodge Division of the McGraw-Hill Companies, Inc. at the county level. The census data come from the 1990 and 2000 U.S. Censuses conducted by the U.S. Census Bureau. We match the characteristics of each census tract to those properties that reside within it using the latitude and longitude coordinates. The construction data from F.W. Dodge are annual statistics on new construction by county over the period 1990 to 2000. Statistics on total construction value (in $\$ 1,000)$ and total construction units are provided.

\section{Using Bank Mergers to Measure Exogenous Competition Changes}

We would like an exogenous measure of banking competition that is otherwise unrelated to any of our dependent variables: demand for financing, financing terms, prices, measures of real activity, and crime. Measuring changes in bank competition for commercial loans directly (e.g., changes in the concentration of bank market share with respect to commercial real estate loans) within a given 
area may be problematic since it is likely that the competitive environment will vary simultaneously with the performance of local real assets and activity. For instance, a decline in a district's property values might lead some banks to withdraw from lending activity in the now less profitable area. Such endogeneity problems will lead to inconsistent coefficient estimates.

One approach to addressing the endogeneity problem is to satiate the regression with as many local market and property attributes as is available. We will add a set of controls which attempt to do this. In addition, we will employ lagged measures of competition to avoid simultaneity problems. However, unobservable differences in local real estate market conditions and property characteristics can also cause endogeneity problems that make detection of an effect difficult in the data. Therefore, we focus on identifying exogenous variation in banking competitiveness and employing instrumental variables techniques. ${ }^{6}$

\section{A. Banking market mergers and acquisitions}

We use non-failing, large commercial bank merger and acquisition activity to measure changes in bank competition that are otherwise uncorrelated with subsequent neighborhood-level variation in loan rates, prices, investment, and crime. As argued earlier, the size and scope of the banks involved in these mergers makes it unlikely that local economic trends are motivating the mergers. Furthermore, Rhoades (2000) documents that mergers and acquisitions are the dominant source of changes in banking structure from 1980 to 1998 as the number of new chartered banks and bank failures is considerably smaller than the number of mergers and acquisitions and accounts for less than 2 percent of local market deposits.

For each property, we compute a measure of bank competition using a local bank loan Herfindahl concentration index. More competitive bank markets are those with lower Herfindahl measures. ${ }^{7}$ We then consider the effects of bank mergers and acquisitions on these Herfindahl measures. As we discuss in Section II.B, the local nature of the commercial real estate market dictates that the local (to be defined shortly) bank concentration index is the relevant measure.

For any given property, $j$, irrespective of the date at which it was sold, we first calculate for each

\footnotetext{
${ }^{6}$ Another approach is to use property fixed-effects estimation to difference out the unobservables, which assumes the unobservable effects are constant through time. However, since we do not have panel data in the sense that almost no properties appear multiple times in our sample, this is not possible.

${ }^{7}$ Our variable is similar to those used in the literature. Berger, Saunders, Scalise, and Udell (1998) examine the effect of bank mergers and acquisitions on small business lending, using bank mergers as a proxy for bank competition. Sapienza (2002) also employs bank mergers on a sample of Italian banks and examines the impact on loan contracts. Other studies that examine the link between merger activity and banking competitiveness are Akhavein, Berger, and Humphrey (1997), Berger and Hannan (1989), Prager and Hannan (1998), Houston and Ryngaert (1994), and Walraven (1997). For evidence that more concentrated banking markets are less competitive, see Berger, Demsetz, and Strahan (1999), Hannan (1997), and Berger, Rosen, and Udell (2001).
} 
year, yr, the actual concentration measure of bank loans for the local area in which the property resides.

$$
\begin{aligned}
\text { BankHI }_{j, y r}^{a c t u a l} & =\sum_{b \in B^{j, y r}}\left(\frac{\# B a n k_{j, y r, b}}{\sum_{b \in B^{j, y r}} \# B a n k_{j, y r}, b}\right)^{2} \\
\# \text { Bank }_{j, y r, b} & =\sum_{i \in N^{(j, y r, b)}} 1
\end{aligned}
$$

where $N^{(j, y r, b)}$ is the set of properties within 15 miles of property $j$ (excluding the property itself) which received a loan from bank $b$ during year $y r$, and $B^{j, y r}$ is the set of distinct banks who made loans to a property within a 15 mile radius of property $j$ in year $y r$.

We then compute a second measure of bank loan concentration BankHI $I_{j, y r}^{\text {merge }}$ using the merger activity data for large, non-failing banks. Specifically, we recompute equation (1) assuming that all bank mergers that took place during the course of year yr actually occurred at the beginning of the year. This creates a hypothetical local bank concentration measure that treats future merged banks as a single entity in their previous deals. That is, if two banks merge during the year, we examine all of their deals before the merger and code them as coming from the same bank in that year. For example, if banks A and B merge in June 1994, we code all deals financed by A or B from January to June as coming from the same bank. We are thus measuring the hypothetical impact on banking concentration based on previous loans made before the merger and assuming that other banks do not change their market shares after the merger. Our measure underestimates the effect of the merger since the activity of the merged bank from June to December is included in $B a n k H I_{j, y r}^{a c t u a l}$, thus ignoring the actual decrease in competition caused by the merger ex post.

The predicted change in banking competitiveness from year $y r_{1}$ to $y r_{2}$ caused by mergers,

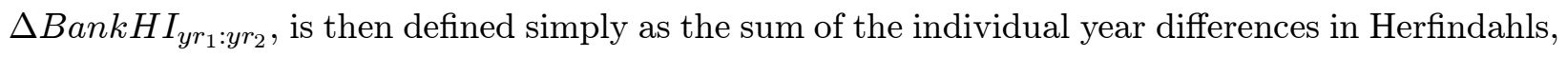

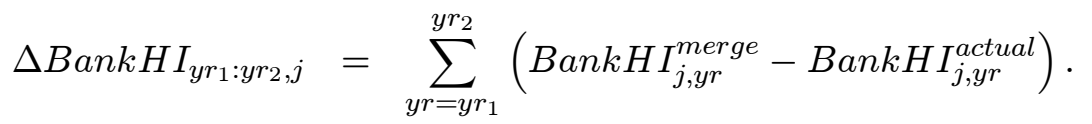

Larger differences between BankHI $I^{\text {merge }}$ and BankHI $I^{\text {actual }}$ across properties (regions) indicate a more substantial potential impact on local commercial real estate loan competition from bank mergers. The range of years we use in calculating $\Delta B a n k H I_{y r_{1}: y r_{2}, j}$ varies across our different tests. For example, since crime risks are available in 1990, 1995, and 2000, we compute $\Delta$ BankH $I_{1992: 1995, j}$ to determine the effect of bank mergers from 1992 to 1995 on the subsequent crime increase from 1995 to 2000. To determine the effect of mergers on rates of loans used to finance individual sales, however, we calculate $\Delta B a n k H I_{1992: s a l e y e a r, j}$, where saleyear is the year in which the $j$ th property 
transacted. We employ the same measure when examining the impact on property prices as well. Finally, since census data are only available in 1990 and 2000, we also compute $\Delta B a n k H I_{1992: 1999, j}$ to examine the impact on census statistics such as income distribution.

Figure 1 reports summary statistics on $\triangle B a n k H I$ measures for various horizons. Focusing on the measure for the whole sample from 1992 to 1999, the mean and standard deviation of $\triangle$ BankH $I_{1992: 1999}$ are 0.0048 and 0.0068 , respectively. Treating all banks equally, a mean plus one standard deviation increase in $\triangle B a n k H I_{1992: 1999}$ translates into a decrease in the number of banks in a local area due to mergers of large banks from an average of 17 to 14 . Figure 1, which plots the histogram of $\triangle$ BankHI measures indicates, however, that the majority of local banking markets experience little or no change in concentration, while a few experience substantial increases. The 90th percentile reduction in the number of banks is 5 , which is fairly substantial. The reduction is even more severe for the fraction of markets most affected by mergers. Such changes can have large marginal effects on loan competition in a local area. Our results are primarily driven by these few areas and we will highlight the characteristics of these areas in the next section. Similar measures

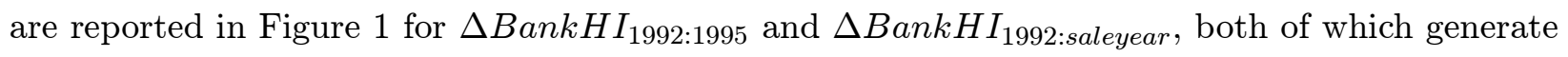
smaller but still sizable changes in banking concentration, particularly in the most extreme areas.

It is worth noting that our study differs from much of the existing literature on U.S. banking competition, in that we make use of a loan-based Herfindahl rather than the more commonly adopted deposit-based measures of concentration. In considering the terms of commercial real estate loans and the effects of those terms on real and social outcomes, a loan-based Herfindahl allows for the most direct analysis of the concentration of the local market for bank debt. While the overlap between local deposit-taking institutions and local loan-making institutions is substantial, it is not complete. For example, the correlation between our loan-based concentration measure and the deposit-concentration measure (calculated at the county-level using data from the FDIC's summary of deposits) in 1995 is 0.39 (significant at the 1 percent level). Outside banks can be quite active in making loans, and banks with sizable local deposits may invest in other sectors of the market. Our loan-based measure also allows us to consider within-county variation in banking market concentration.

\section{B. What is the size of the local banking market?}

The standard definition of the local banking market in the literature is the local Metropolitan Statistical Area (MSA) or non-MSA county (e.g., Prager and Hannan (1998), Berger, Demsetz, 
and Strahan (1999), Rhoades (2002), and Black and Strahan (2002)). As described above, we define the local banking market to consist of the 15 mile radius around a property, and in much of our empirical analysis we include county fixed effects. Our definition of the local banking market is finer than that usually employed and requires some explanation.

First, there is evidence from survey data for households and small businesses that banking markets are highly localized even within counties (see Kwast, Starr-McCluer, and Wolken (1997) and Petersen and Rajan (2002)). Kwast, Starr-McCluer, and Wolken (1997), for example, show that the median and 75th percentile of the distances between small businesses and the financial institutions providing their mortgage loans are 4 and 12 miles, respectively. This suggests that a definition of a local banking market that is narrower than the MSA-level or non-MSA-countylevel is appropriate. Part of the rationale for the standard definition of a local banking market is data availability, and our highly detailed data allow us to explore within-county variability in credit conditions. It is possible, however, to use a banking market definition that is too fine. For example, it is unreasonable to suggest that firms ignore banks located more than five miles away. The survey data and previous research in commercial real estate loan markets suggest that 15 miles is an appropriate choice of radius (Garmaise and Moskowitz, 2004).

Second, a principal advantage of our neighborhood-level variable is that we are able to include county fixed effects in our regressions. One might imagine many reasons for credit terms to evolve differently in different counties (e.g., county or state-level regulatory changes), and our county fixed effects net out these effects. In addition, it is much less plausible that billion dollar or larger bank mergers are driven by neighborhood-level changes in the economic environment within a county giving us greater confidence in the exogeneity of our merger-induced concentration variable. ${ }^{8}$

Third, for comparability with the previous literature, in Section V we consider county- and state-level measures and find very similar results. In addition, in unreported regressions, we find that our results are robust to using a local banking market radius of either 10, 20, or 25 miles.

\section{Bank Mergers' Impact on Financial, Real, and Social Activity}

In this section we examine the subsequent impact on financial, real, and social activity from restricted credit access as a result of decreased bank competition from large mergers.

\footnotetext{
${ }^{8}$ It is interesting to note that our results are considerably strengthened when we discard the county controls.
} 


\section{A. Loan rates and borrowing activity}

We begin by analyzing in Table 2 how the predicted change in bank Herfindahl concentration measure generated through non-failing, large bank mergers is linked to actual future loan concentration, rates, terms, and loan size of the property-specific transactions in our sample.

In our first test, we show that bank mergers do have a significantly positive effect on subsequent actual changes in banking market concentration. In the first column of Table 2 we display the results from regressing the actual change in the local banking market Herfindahl index from the first to the second half of our sample (from 1992 to 1995 to 1996 to 1999) on the merger predicted concentration measure, $\Delta B a n k H I_{1992: 1995}$, and a set of control variables that include the 1995 property crime index risk and recent growth in crime (from 1990 to 1995), local price variation, defined as the cross-sectional variation of capitalization rates on all properties within 15 miles of the property (excluding the property itself), as well as growth in population, income, and median home value from 1990 to 2000 for the census tract in which the property resides. A constant and fixed effects for property type and county are also included. Regressions are run under OLS with robust standard

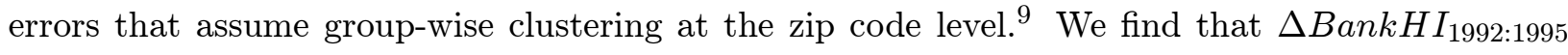
strongly predicts increased bank loan concentration over the subsequent three year period. This indicates that bank mergers make the local market less competitive over the following three years, justifying their use as an instrument for market concentration.

The effects of bank mergers on local loan market conditions are analyzed in columns two through four of Table 2. We regress the interest rates on loans being made on $\Delta B a n k H I_{1992: s a l e y e a r}$ and all the controls from the first regression. We also include a set of loan attributes as regressors: the loanto-value ratio, indicator variables for floating or fixed rates, whether the loan is backed by the Small Business Administration, and the length of amortization and loan maturity in years. In addition, we add year and bank fixed effects to the regression (for all banks, not just large banks) in order to measure deviations in loan rates from the average rate charged by a particular lender in a particular year. This will control for unobservable quality differences or lending practices across banks as well as time effects. The second column of Table 2 reports results from the loan rate regression. As the table indicates, when bank mergers increase the concentration of the local banking market the increase in loan rates is statistically and economically significant. Thus, given the bank fixed effects, the same bank is charging higher rates in less competitive areas than elsewhere.

\footnotetext{
${ }^{9}$ The number of clusters is reported at the bottom of the table along with the total number of observations. For column 1 this means that although there are 22,317 data points, we are treating the data as if there are only 1,147 independent observations, resulting in conservative standard errors.
} 
To gauge economic significance, we consider the distribution of $\Delta B a n k H I_{1992: s a l e y e a r}$ over all data points for which $\Delta B a n k H I_{1992: s a l e y e a r}$ is positive, since the large fraction of the data for which there is no predicted change in concentration (e.g., $\Delta$ BankH $I_{1992 \text { saleyear }}=0$ ) is uninformative about the effects of mergers on loan terms. To assess economic significance we consider only the conditional variation in $\Delta B a n k H I_{1992: s a l e y e a r}$ that remains once the variation explained by the fixed effects is removed. An increase from the 5th percentile to the 95 th percentile in this residual variation is 0.0122 , which translates into raising average loan rates at the margin by 40.1 basis points per annum or a 5 percent increase over the mean loan rate of $8.1 \%$. The magnitude of this price effect associated with an increase in market concentration is consistent with previous results in the literature (Hannan (1997) and Sapienza (2002)). ${ }^{10}$ An increase of 40.1 basis points in loan rates likely discourages investment and may forestall projects. This suggests that the broader effects of mergers on local economic environments are likely to be most important in areas that experience the most extreme concentration increases.

Increases in bank concentration affect not only the price of credit, but its quantity as well. In Column 3 we estimate the probability of obtaining any bank debt using a linear probability model with the fixed effects and standard errors clustered at the zip code level. ${ }^{11}$ As Column 3 indicates, borrowers appear to receive bank financing less frequently when banking markets become less competitive, although this result is not statistically significant $(t$-statistic $=-1.60)$. However, our data do not allow us to account for borrowers who are discouraged by credit conditions and deterred from seeking loans at all. Column 4 reports results from the regression of the magnitude


debt significantly decreases when bank competition declines. ${ }^{12}$ A 90th percentile increase in the conditional variation of concentration reduces the amount of bank debt by 2.5 percent.

\section{A.1 Value-weighted concentration measures}

The concentration measure we analyze in Panel A is the one described in equation (1): a variable that equal-weights all loan transactions. We adopt an equal-weighting approach because it is likely

\footnotetext{
${ }^{10}$ The literature finds that mergers between small banks can benefit borrowers (Peek and Rosengren (1998), Strahan and Weston (1998), Sapienza (2002)), while Peek and Rosengren (1998) and Sapienza (2002) find evidence of market power effects when large banks are acquired. Since we focus on large bank mergers, our results seem in line with previous evidence.

${ }^{11}$ We have also employed conditional logit and the robust semiparametric estimators of Klein and Spady (1993). Since the results from these models were qualitatively similar and generated the same conclusions for the paper, we only report the OLS estimation results for brevity.

${ }^{12}$ Since borrowers can substitute cash or seller financing for bank debt, some of the dependent variable's observations are zero. A truncated regression (Cragg, 1971) yielded coefficient estimates similar to the OLS results reported.
} 
that small loans, which are typically serviced by local banks, will be most affected by mergerinduced increases in local market concentration. Indeed, we provide evidence in support of this hypothesis below. As a robustness check, however, in Panel B of Table 2 we report regressions of future banking market concentration and loan characteristics on a value-weighted merger-induced concentration measure. As shown in Panel B, the value-weighted results are essentially parallel to the equal-weighted results and provide additional evidence that large bank mergers have significant effects on future loan terms. Since results are similar using either measure, for brevity we report results for the equal-weighted measure throughout the paper.

\section{A.2 Short-term distortions and long-term equilibrium}

Consistent with the results in Panels A and B, Sapienza (2002) finds that after mergers, banks engage in less small business lending. Berger, Saunders, Scalise, and Udell (1998) and Berger, Bonime, Goldberg, and White (2000), however, show that merged banks' competitors increase their small business lending in response so that the net effect on small business lending is unclear. We can reconcile these findings with our results by considering the timing of our transactions. We measure the effect of the change in competition on loan rates over the period 1992 to the sale year of the property. On average this is a 3.5 year period. We posit that a change in the regulatory or technological environment motivates two banks to merge. This merger then affects the competitive environment and results in higher loan rates and smaller loans being provided. This short-term distortion of the market will typically provoke entry or loan supply increases by competing banks, but as Berger, Saunders, Scalise, and Udell (1998) note, these competitive effects will require a minimum of three years to be realized. In the interim, the loan market perform inefficiently with a diminished level of financing, and this is the effect we are capturing.

To test this idea in our sample, in Panel C Column 1 of Table 2 we regress the change in bank concentration from 1998 to 1999 on predicted changes in concentration due to mergers 4 to 6 years ago $\left(\triangle B a n k H I_{1992: 1994}\right)$ and due to mergers in the most recent three years $\left(\Delta B a n k H I_{1995: 1997)}\right.$. The 1998 to 1999 period is the only one for which a six year precursor period is available. All of the previous control variables are also included in the regression. Merger-induced increases in banking concentration over the most recent prior three years lead to an increase in actual concentration: the coefficient on $\Delta$ BankH $_{1995: 1997}$ is significantly positive. Increases from the more distant three year period, however, lead to decreases in actual concentration: the coefficient on $\Delta B a n k H I_{1992: 1994}$ is significantly negative. These results provide strong evidence that recent mergers lead to short-term 
decreases in competition, but over the longer term new entry and loan supply increases lead to a restored competitive equilibrium, consistent with results in the literature.

Columns 2 through 4 of Panel C provide compelling evidence from the loan markets that bank mergers cause a short-term disruption to the competitive landscape. We find that increases in $\triangle$ BankH $I_{1995: 1997}$ significantly increase interest rates, decrease loan frequency, and decrease loan size, but the effects of $\Delta B a n k H I_{1992: 1994}$ are uniformly insignificant, and of the opposite sign in the frequency and size regressions. Mergers in the last three years seem to worsen loan terms, but mergers from the more distant three year period appear to have no residual effect, consistent with a short-term competitive distortion.

\section{A.3 Robustness: Deals and mergers that should have no competitive effects}

One way to increase confidence in the plausibility of our story is to examine a set of deals that should be unaffected by local competition and a set of mergers that should have little competitive impact and show that these do not affect actual loan concentration or credit conditions.

Panel D of Table 2 provides results on the effect of bank mergers on loan terms for the very largest deals, property values of at least $\$ 10$ million. Borrowers in the largest deals will typically have access to a broader set of national banks and are thus less likely to be affected by changes in the competitiveness of the local banking market. Consistent with this, Panel D shows that an increase in local bank market concentration has no effect on loan rates, loan frequency, or loan size for the largest deals.

In Panel E of Table 2, we consider the effects of a merger between two banks owned by the same bank holding company (BHC). We hypothesize that such a merger is essentially an internal corporate reorganization and that it should therefore not have a competitive effect. Indeed, this is our motivation for excluding such mergers from our main competition measure. Calculating a new $\triangle$ BankHI measure using only within-BHC mergers, we find that such mergers have no effect on subsequent actual concentration, interest rates, loan frequency, or loan size, as predicted.

Finally, Panel F of Table 2 analyzes the effects of mergers of failing banks. We exclude such mergers from our main $\triangle B a n k H I$ measures because of greater endogeneity concerns with regard to declining economic conditions and because the disappearance of a failing bank likely has only a small effect on competition. While we do find that mergers of failing banks lead to slightly increased concentration, such mergers have negligible effects on loan terms, consistent with failing banks having little competitive effects and mitigating endogeneity concerns. 


\section{B. Real activity and the local economy}

We next analyze the potential real effects of the substantial decrease in the provision of bank debt associated with large mergers in the local economy.

\section{B.1 Investment and development}

The first two columns of Table 3 Panel A consider two proxies for the level of development in the 15 mile radius surrounding each property. In the first column we consider the change in mean age of properties and in the second the change in the fraction of properties less than 3 years old in this region (we exclude the property itself). The change in average age of properties sold in a local area indicates how much recent development has taken place in the area, since recently developed properties will be young by definition. The fraction of properties less than three years old compares the level of new development from 1995 to 1998 to the level of development from 1992 to 1995 . We regress these development variables on $\Delta B a n k H I_{1992: 1995}$ and the set of control variables.

As the table indicates, the average age of properties rises significantly and the fraction of new/developed properties declines significantly when local banking markets become less competitive. A 90th percentile increase in the conditional variation of $\Delta B a n k H I_{1992: 1995}$ raises the mean age by 1.01 years and drops the fraction of new properties by 0.125 percent. Since the mean age of properties is 35.55 years and 10 percent of properties are 3 years of age or younger, this increases the mean age by 2.9 percent and decreases the fraction of new properties by 1.2 percent. These results linking investment to well-functioning credit markets are consistent with the cross-country work of King and Levine (1993), Rajan and Zingales (1998), and Demirguc-Kunt and Maksimovic (1998) and the within-country work of Guiso, Sapienza, and Zingales (2004).

\section{B.2 Property prices}

Neighborhoods with less new development will age and become less attractive with time as properties depreciate. This may in turn impact local real estate market prices and rents.

Column 3 of Panel A reports regression results of property prices on $\Delta B a n k H I_{1992: s a l e y e a r}$. The dependent variable is the property capitalization rate (net operating income divided by price). The measure $\Delta B$ ankH $I_{1992: s a l e y e a r}$ is appropriate for this test since we are considering property prices reported in the year of the sale. We include the controls from previous regressions.

The regression demonstrates that cap rates increase significantly, or prices per unit of income decrease significantly, when the banking market becomes more concentrated. A 90th percentile 


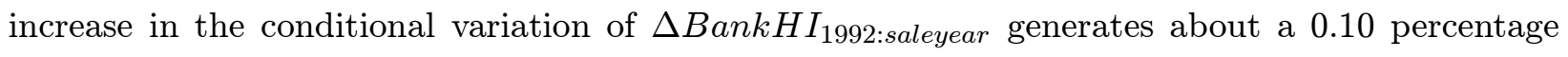
point increase in cap rates, which implies a 1 percent decrease in property prices (the mean cap rate of 10.09 percent is given in Table 1). Given that the mean property value in our sample is $\$ 2,387,000$, this translates roughly into a $\$ 23,870$ decline.

Taken together, the results in Table 3 Panel A show a general local deterioration from increased bank concentration (due to mergers), as real estate investment declines and property values fall.

\section{B.3 Income distribution, unemployment, and homeownership}

We next consider the effects on the income distribution of the neighborhood. To analyze this, we make use of data from the 1990 and 2000 Censuses. The results in Table 2 and Table 3 Panel A illustrate the effects of mergers on subsequent loan contracts, development, and prices, so any changes in these latter variables are interpreted as being caused by mergers. For the census data this is not possible, since given the time frame of our data we can only measure contemporaneous changes in the merger and census variables. (One exception is the in-migration income test described below.) This suggests a measure of caution in attributing causality to the following results, though we think these findings are nonetheless interesting and supportive of our central hypothesis. We again defer a detailed examination of the general question of causality to Section IV.

In the first column of Table 3 Panel B we display results from regressing the percentage change (from the 1990 to 2000 Censuses) of median household income on $\Delta B a n k H I_{1992: 1999}$. We find a highly significant negative relationship: a 90th percentile increase in conditional bank concentration reduces median income by about $3.9 \%$. However, much of this income change is due to an exodus of wealthier households from the tract and influx of poorer households into the area. In the second column of Panel B we show this migration of poorer households into the neighborhoods experiencing increases in bank concentration. We regress the ratio of income of households who moved into the tract in the last five years over the income of households who have resided in the tract for at least five years on $\Delta B a n k H I_{1992: 1995}$. We find that neighborhoods with increased bank concentration in 1992 to 1995 experience an inflow (outflow) of relatively poorer (wealthier) residents in the period 1995 to 2000 . Hence, the $3.9 \%$ reduction in income is a netting of these two migration effects.

Consistent with this evidence, we also show in the third column of Panel B that unemployment in a property's census tract rises with an increase in bank concentration. In column 4 we further show that income dispersion, defined as the standard deviation of the fraction of households in the eight census income categories, ranging from less than $\$ 15,000$ to more than $\$ 150,000$, in the 
property's census tract, increases significantly with bank concentration, despite the fact that median income drops. This may be because the poor are disproportionately affected by credit restrictions. The final column of Panel B considers the change in total vacancy and rental rates from 1990 to 2000 in the census tract in which the property resides. The positive coefficient indicates that home ownership rates decline as bank concentration increases.

\section{Crime}

There is substantial evidence in the economics of crime literature of a positive relationship between unemployment and crime (e.g., Freeman (1999) and Freeman and Rodgers (1999)), though the association is not overwhelmingly strong (e.g., Cullen and Levitt (1999)). Grogger (1998) and Gould, Weinberg, and Mustard (2002) present clear evidence linking low legal wage opportunities to increased crime. Kelly (2000) and Fajnzylber, Lederman, and Loayza (2002) document that crime increases with economic inequality. The results in Table 3 that increases in bank concentration lead to less development and lower prices, and are associated with an influx of poorer households and rising income inequality, suggest a potential causal connection between bank merger-induced concentration and increased crime. Moreover, given potential social interaction multiplier effects of the type suggested by Glaeser, Sacerdote, and Scheinkman (1996, 2002), the effect on crime could be significant. It is also a general finding of the crime literature that unemployment, income, and income dispersion are strongly related to property crime, while the association between economic variables and personal (violent) crime is much weaker and perhaps nonexistent (Levitt (2001), Raphael and Winter-Ebmer (2001), and Nilsson (2004)). Therefore, we examine how property crimes and personal/violent crimes each change when banking markets become less competitive through non-failing large bank mergers. We should not expect to find much of an effect on the latter according to our proposed mechanism.

The dependent variable in the first column of Table 4 Panel A is the percentage change in burglary risk from 1995 to 2000 for the eight digit latitude and longitude location of the property. The dependent variable in column two is the analogous change in general property crime. In all regressions in this table we include a constant, county dummies, and property type dummies which are omitted from the table for brevity as well as the other control variables. Since the change in banking competitiveness is measured using only past transaction data, it should not exhibit endogenous correlation with the dependent variable, future crime risk. Since crime risks are likely to be serially correlated, however, we also include both the current level of crime (in 1995) and the 
most recent increase in crime (from 1990 to 1995) as controls in the regression.

The first two columns of Table 4 Panel A show that $\Delta B a n k H I_{1992: 1995}$ significantly increases burglary and general property crime risk from 1995 to 2000. Hence, when large, non-failing bank mergers cause the local banking market to consolidate and become less competitive, there is a subsequent rise in burglaries and general property crimes over the next several years.

Columns 3 and 4 of Panel A employ homicide and personal crime risk as dependent variables. As indicated in Table 4, $\Delta$ BankH $I_{1992: 1995}$ has an insignificant effect on both homicide and personal crime risks. These insignificant results are consistent with the evidence from the crime literature described above that there is little connection between economic variables and personal crime. Note, too, that the other local economic indicators used as controls also have little effect on personal crime. The fact that mergers increase property crime risks while having no effect on personal crime risks is consistent with the idea that the mechanism through which mergers increase crime is through a negative effect on the overall economic environment, highlighted in Tables 2 and 3.

For robustness, the fifth and sixth columns of Panel A include the level of bank concentration over the period 1992 to 1995 as an additional variable. The results are essentially unchanged by the inclusion of this control.

To gauge the magnitude of the effect of bank mergers on crime and how it compares to documented economic variable-crime relationships in the literature, we compute the elasticity of crime to merger-induced bank concentration by regressing the percentage change in future crime on the percentage change in $\Delta B a n k H I_{1992: 1995}$, defined as

$$
\% \Delta \text { BankH }_{1992: 1995, j}=\frac{\sum_{y r=1992}^{1995} \text { BankH }_{j, y r}^{\text {merge }}}{\sum_{y r=1992}^{1995} \text { BankH } I_{j, y r}^{\text {actual }}} .
$$

The results are reported in the two columns of Table 4 Panel B. The elasticities of burglary and property crime with respect to bank concentration are 0.16 and 0.18 , respectively. A 90th percentile increase in $\% \Delta B a n k H I_{1992: 1995}$ (conditional on the fixed effects) raises the burglary risk by 0.56 percent and the property crime risk by 0.63 percent. The magnitudes of the crime effects that we document are in line with those in the literature. Grogger (1998), for instance, estimates an elasticity of property crime to wages of 0.6 to 0.9 . Rickman and Witt (2003) find an elasticity of theft to unemployment of approximately 0.75 . Given that mergers affect crime indirectly, through an economic mechanism, we would expect the crime-bank concentration elasticity to be lower than that for direct economic variables such as unemployment and wages. 


\section{C.1 Interactions with local market characteristics}

It is interesting to investigate the types of neighborhoods most affected by credit supply shocks induced by mergers, particularly given the skewed distribution of these effects evident in Figure 1. In Table 4 Panel C, we consider differences across neighborhoods in the effect of a merger-induced increase in bank concentration on burglary and property crime. A priori, it seems reasonable that the most disadvantaged neighborhoods are likely most affected by a given increase in bank concentration since the provision of finance in these neighborhoods may already be restricted. We regress the change in burglary and property crime risks from 1995 to 2000 on $\Delta$ BankH $I_{1992: 1995}$ and $\Delta B a n k H I_{1992: 1995}$ interacted with other local market variables. In the first and sixth columns of the table we show that an increase in $\Delta B a n k H I_{1992: 1995}$ has the greatest effect in increasing crime in neighborhoods that previously already had higher bank concentrations. Columns 2 and 3 and 7 and 8 show that an increase in bank concentration has a significantly greater effect on crime in neighborhoods with initially greater income dispersion and higher crime levels in 1990, respectively. The regressions described in columns 4 and 9 show that the effect of mergers on crime is significantly greater in areas with lower 1990 median incomes as well. In columns 5 and 10 we report results from regressions that include all the interactions. Interactions of our merger variable with previous bank concentration and median income remain significant in these regressions.

These results indicate that more fragile neighborhoods already experiencing concentrated loan

markets and low median income are more affected by an increase in bank concentration arising from mergers. Given the skewed distribution across neighborhoods of the effect of mergers on loan competition, it appears that our results are driven by a few extreme areas already in a fragile state with high initial loan concentration, where a large bank merger may tilt the neighborhood into further deterioration. Clearly, mergers per se are not uniformly bad, but in delicate and marginal areas they seem to have significant competitive effects that generate economic and social consequences. Furthermore, given potential social multiplier effects suggested in the literature, it may not take much to send a marginal neighborhood spiraling downward, though we can provide no further evidence of such multiplier effects.

\section{C.2 The broader implications of bank merger-induced crime}

To put our crime results into perspective, consider the total number of property crimes committed each year in the United States. The FBI documents that the average number of property offenses was 11.1 million per year from 1995 to 2000 (our sample period for crime changes). Assuming 
that the mean change in banking concentration through mergers we observe in our data set from 1992 to 1995 (0.1 percent) applies nationally, this would translate into roughly an additional 24,300 property crime offenses from 1995 to 2000, due solely to competitive effects from large bank mergers. Although a small fraction of total property crime, such increases clearly have significant utility and social consequences (see Becker (1968) and Ehrlich (1973)).

\section{Exogeneity of Competition Measure}

We have argued that the use of non-failing, large bank mergers from the past provides an exogenous measure of future competition changes in local areas. We now provide further evidence on the exogeneity of the bank merger variable, particularly with regard to crime.

\section{A. Does (whatever drives) future crime spur present-day mergers?}

The regression results in Tables 2, 3, and 4 point to a link between bank mergers, loan terms, real activity, and crime. Moreover, we have been careful to link bank merger activity to subsequent increases in loan terms and crime. One interpretation of this link is a causal one, namely that mergers reduce financial access, which leads to neighborhood declines and subsequent increases in crime. The leading alternative explanation for these correlations, however, is reverse causation, namely that whatever unobservable variables affect future crime drive present-day mergers. For example, local economic conditions affecting future crime risks may motivate bank mergers today. One version of the reverse causation theory is that banks in declining neighborhoods may anticipate further deterioration in their future lending positions. Concerned about their viability or falling below minimum efficient scale, the banks may seek mergers. Another version is that banks in declining neighborhoods may understand that the equilibrium level of competition in such neighborhoods is likely to decline in the future as the profitability of the neighborhoods decline. Banks may therefore merge today to reduce future competition in these neighborhoods.

\section{A.1 Arguments against reverse causality}

We believe that the reverse causal interpretation of our results is less plausible for several reasons. First, commercial real estate loans typically comprise a small portion of a bank's balance sheet. For example, the FDIC's History of the Eighties - Lessons for the Future (p. 159) documents that among non-failing banks, commercial real estate loans were only 11 percent of assets in 1993. Over the entire 1992 to 1999 period, the Federal Reserve estimates that total real estate loans 
(commercial and residential) comprised less than 13 percent of assets. Since we only consider non-failing mergers, and since commercial real estate loans are a small fraction of bank assets, it is unlikely that changes in commercial property values or commercial real estate lending is driving the mergers we study. Moreover, in Table 3 we showed that even an increase in banking concentration at the 90th percentile produced only a 1 percent decrease in property values. The effect on the value of the bank's loan would be even smaller. For these reasons it is unlikely that banks are merging in anticipation of future decreases in property values and increases in crime.

Second, we include county fixed effects in our analysis. It seems unlikely that bank mergers are motivated by neighborhood-level variation within counties in current or anticipated future crime risks or economic declines. This is especially true of the particular mergers we use, whose size (at least $\$ 1$ billion in assets) and scope (operating in many neighborhoods) implies that the average neighborhood effect for these banks (controlling for county effects) is likely to be quite small, by the law of large numbers. Therefore, cross-neighborhood variation in real estate prices and crime is very unlikely to motivate the mergers of these large banks.

Third, in the next section we will employ another measure of bank competition using state branching deregulation as an instrument rather than mergers, and find very similar effects. It seems unlikely that both instruments would be contaminated by the same endogeneity concerns, lending strong support for these variables capturing exogenous competition changes.

\section{A.2 Testing reverse causality directly}

To provide clear evidence for or against the reverse causation theory we test several of its implications in Table 5. First, if trending crime risks cause mergers, future crime would have to be a reflection of the current crime trend; in essence, current crime would be spurring contemporaneous bank mergers. We note that the recent change in crime (from 1990 to 1995) is positively correlated with future changes in crime (from 1995 to 2000). Hence, under this alternative hypothesis we should see a significant positive contemporaneous correlation between mergers and crime in the period 1990 to 1995. As the first two columns of Table 5 Panel A indicate, however, we find no such relation in the data. The contemporaneous correlations between burglaries or property crime and our merger variable are statistically no different from zero.

We also examine in columns 3 and 4 of Table 5 Panel A whether recent changes in crime or eco-

nomic activity, census-tract-level income growth and home value growth, predict future actual bank concentration, capturing the effects of both mergers and market consolidation occurring for other 
reasons. Neither burglary nor property crimes nor income growth predicts future bank concentration, but home value growth at the census tract level predicts reduced future bank concentration with marginal statistical significance. This suggests that declining neighborhoods are more likely to experience future bank consolidation, which is consistent with a version of the reverse causation hypothesis.

In our analysis, however, we are careful not to use the actual future change in bank concentration, but rather the concentration increase induced by previous mergers. It is precisely because of our concern that future bank concentration may be endogenously related to crime that we use previous large mergers as an instrument. In columns 1 and 2 of Table 5 Panel B, we regress the measure of future merger-induced concentration $\Delta B a n k H I_{1996: 1999}$, as opposed to actual concentration, on past crime, income growth, and home value growth. None of these variables predicts an increase in merger-generated concentration. These results stress the importance of using an instrument for bank competition via large, non-failing bank mergers and undermine the reverse causation theory; there is no evidence that large bank mergers are taking place due to neighborhood declines.

In columns 3 and 4 of Table 5 Panel B we address whether crime predicts merger activity directly by regressing the probability of a merger of any bank active in a property's neighborhood (linear probability model) on the change in crime, income growth, and home value growth. Crime risks predict significantly fewer mergers, while the economic variables are insignificant. This suggests that areas suffering from crime increases are less likely to experience a merger, which is contrary to the reverse causation hypothesis. Thus, it is not the case that mergers are associated with future crime increases because banks in declining areas merge.

\section{B. Failing banks and non-lending institutions}

Although our merger variable is constructed from only mergers between large, non-failing commercial banks, in columns 1 and 2 of Table 5 Panel $\mathrm{C}$ we consider the effects of mergers that involve failing banks exclusively, requiring assistance from either the FDIC, RTC, NCUA, state or other regulatory agency. If bank mergers increase subsequent crime rates due to a competitive effect, then these assisted mergers should have little impact on future crime. Failing banks are likely not providing much competition for other banks before the merger so their removal from the market should not typically have a significant effect. On the other hand, if the association between bank mergers and future crime arises from mergers of weak banks in declining neighborhoods (reverse

causality), then the effect should be strongest for these assisted mergers, since failing banks are 
more likely to be active in declining neighborhoods. Our data contain an additional 18 failing banks who merged in our sample. We recompute the bank merger concentration measure using these banks only and regress future crime risk changes on it. We find an insignificant coefficient for burglary, and a marginally significant but negative coefficient for property crimes, contradicting the reverse causal story and providing further support for a causal link from non-failing bank mergers to future crime.

For further robustness, columns 3 and 4 report results from regressing the 1995 to 2000 changes in crime risks on changes in the number of non-lending financial institutions from 1990 to 1995, obtained from the County Business Patterns of the Bureau of Economic Analysis. ${ }^{13}$ Under a reverse causation theory, economic decline should cause both a decrease in the current number of non-lending financial institutions and a future increase in crime, leading to a spurious negative correlation between the two, in analogy to the reverse causal argument for bank mergers and crime. If, on the other hand, our conjecture that the merger of banks causes an increase in crime through poorer credit conditions, then a decrease in non-lending financial institutions should not have any effect on future crime, since these institutions themselves do not affect loan supply. As the last two columns of Table 5 indicate, there is no evidence of an association between the number of nonlending financial institutions and future crime risks. This does not support the reverse causation theory, but is consistent with our story of credit access, development, and social spillovers.

\section{Separating the merger effect from the competition effect}

As an additional test of the exogeneity of our instrument, we separate the effect of the merger per se from the effect of reduced competition caused by mergers. Specifically, we augment our $\triangle$ BankHI measure with a dummy variable equal to 1 if a merger took place in the local banking market and zero otherwise. The dummy variable contrasts local markets where a merger took place with those where one did not, making no distinction between the potential impact of the merger on competition using prior bank concentration information. We propose the merger-presence variable as a means of capturing the non-competition aspects of a merger, such as those arising from reverse causation or other unobservables.

Panel A of Table 6 reports the effect of the merger itself (the dummy variable) on loan rates, loan size, and crime risks. The merger itself does not have the effect on loan terms and crime

\footnotetext{
${ }^{13}$ Non-lending financial institutions are defined as the number of establishments with NAICS codes of 523 (securities, commodity contracts, and other financial investments), 524 (insurance carriers and related activities), and 525 (funds, trusts, and other financial vehicles), obtained at the county level.
} 
risks predicted by the reverse causation hypothesis. Controlling for the effect on the competitive environment, mergers per se have no statistically significant effect on loan rate, burglary risk, and property crime risk and have a positive effect on loan size, which is of the opposite predicted sign. The coefficients on $\triangle B a n k H I$ show that it is the extent of the merger-induced diminution in competition, not the fact of the merger, that predicts economic and social activity.

Panel B reports results for mergers with no predicted competitive effects exclusively, where we examine the merger dummy variable conditional on $\triangle B a n k H I=0$. This considers all mergers in which outsider banks purchase an insider bank operating in a neighborhood, where the ex ante expected change in local bank concentration is zero. Hence, there should be little effect on local competition associated with these mergers according to our story. On the other hand, if mergers are motivated by declining neighborhoods (reverse causation), then these outsider-insider mergers will be associated with the outcome variables. As Panel B details, mergers in which outsider banks acquire insider banks, which should have no local competitive effects, indeed do not significantly predict changes in loan rates, burglary risk, or property crime risk, and are associated with larger, rather than smaller, bank loans. These findings are inconsistent with the reverse causation hypothesis and support the exogeneity of competition being captured by our measure.

We have shown that crime increases are not correlated with contemporaneous or future bank mergers. Neighborhood-level economic variables are not associated with the likelihood of a merger. Failing-bank mergers, which should be most affected by declining neighborhoods, are not correlated with future increases in crime risk. Decreases in the number of non-lending financial institutions do not predict increased crime. It is the decrease in competition, not the fact of the merger, that predicts future crime increases, and mergers between outsider and insider banks, with no local competitive effects, are not correlated with future rises in crime. In the face of this collection of evidence, the contention that banks are merging in anticipation of future neighborhood-level decline strikes us as not very plausible.

\section{County and State Level Regressions}

For robustness, we supplement our neighborhood-level evidence with county and state level evidence from bank competition. This provides an additional test of our hypothesis, additional variables not available at the neighborhood level, and out of sample evidence on crime from another data source and over another time period. In addition, state level data allow for the use of another exogenous measure of competition using state branching regulation. 


\section{A. County level construction and crime}

While migration is likely to be less important at the county level than at the neighborhood level, a merger-induced constriction of credit should still have implications for construction and crime at the county level. One advantage of using county-level data is that explicit construction estimates are available. We are also able to use the FBI UCR at the county level to compare to the Cap Index crime scores. This provides further robustness.

In the first two columns of Table 7 Panel A we regress the county-level changes in number of construction companies and employees from 1995 to 2000 on $\Delta B a n k H I_{1992: 1995}$, the level and change in property crime risk, and the usual controls. The construction data come from the Bureau of Labor Statistics and the Bureau of Economic Analysis County Business Patterns. For these county-level regressions we include state fixed effects and compute standard errors assuming group-wise clustering at the county level. The results show that increased merger activity in 1992 to 1995 strongly predicts a reduction in both the number of construction companies and construction employees in the subsequent period.

Columns three and four examine the impact of bank mergers on development by employing construction data from F.W. Dodge Division of the McGraw-Hill Companies, Inc. The change from 1995 to 2000 in the total value of construction (in $\$ 1,000$ ) and in the number of units being constructed are regressed on $\triangle B a n k H I_{1992: 1995}$ and the standard controls. As the table indicates, the value and number of units both decline when local banking markets become more concentrated.

Panel B reports results from regressions of county-level crime rates (reported crimes per capita) from the FBI's UCR on our measure of merger-generated increases in bank concentration. In column 1 we show that the number of reported burglaries per capita increases with our bank concentration variable. This is consistent with our previous evidence from neighborhood-level regressions using CAP Index data. In column 2 we report that the number of reported homicides per capita is not significantly predicted by the bank concentration variable, which is also consistent with our previous results. These results support the hypothesis that bank mergers increase future crime through their negative effect on the economic environment, which the crime literature shows is closely linked to property crimes such as burglary but not violent crimes or homicides.

In columns 3 and 4 of Panel $\mathrm{B}$, we introduce control variables for the lagged average state abortion rate (the average number of abortions per 1,000 live births) from 1982 to 1986 and the log of the imprisonment rate (number of prisoners per capita) from 1994 to 1995 in place of state fixed 
effects. ${ }^{14}$ The results show that merger-induced bank concentration increases burglaries and has no significant effect on homicide, even after controlling for the lagged abortion and imprisonment rates, both of which have been shown to capture substantial variation in crime (Levitt (1996), Donohue and Levitt (2001)).

\section{B. State branching deregulation: An out of sample test}

As a final test, we employ another exogenous measure for changing bank competition using state variation in bank branching regulation. Black and Strahan (2002) use changes in intra- and interstate banking and branching regulation to instrument for banking competitiveness and examine the impact on small business lending as proxied by the number of incorporations in a state. Branching liberalization is linked to branch openings, new entrants, and increased number of incorporations and borrowing activity. Most of this regulation takes place in the 1970s and 1980s, however unrestricted branching was adopted in some states during the 1990's, providing some variation on state bank regulation over our sample period from 1992 to $1999 .{ }^{15}$ Specifically, we employ the number of years since the state first allowed unrestricted bank branching, which usually meant that a bank could open a new branch anywhere in the state. This variable takes on the value zero if the state had yet to institute unrestricted branching at the time of the property sale. Unrestricted branching should increase competition in local bank markets, hence we expect this variable to have effects opposite those of mergers.

The first column of Panel A of Table 8 reports results from regressions of local bank concentration on unrestricted branching in a state. The usual controls for each regression apply, but standard errors are calculated assuming group-wise clustering at the state and year level. As the table indicates, unrestricted branching decreases subsequent bank concentration levels in neighborhoods. Hence, deregulation seems to increase competition. The next three columns examine the impact of deregulation on loan rates, loan sizes, and prices. Consistent with our earlier findings, loan rates decrease with competition and loan sizes and prices increase with competition. The magnitude of the effects is smaller though similar to those obtained via the merger variable for competition.

In Panel B, we examine crime rates at the state level in conjunction with branching deregulation.

\footnotetext{
${ }^{14}$ The abortion data come from the Alan Guttmacher Institute surveys from the Bureau of the Census United States Statistical Abstract and the prisoner population data come from Correctional Populations in the United States from the Bureau of Justice Statistics. These measures are employed by Donohue and Levitt (2001) and were graciously supplied by the authors.

${ }^{15}$ California, Washington DC, Maryland, Nevada, and New York all adopted unrestricted branching in the early to mid 1970's, Massachusetts, Oregon, Texas, and Virginia adopted in the late 1980's, Illinois in 1993, and Colorado and Georgia had not adopted by 1997.
} 
Since we are using state branching deregulation and crime rate data at the state level from the FBI's UCR, we are no longer restricted to the COMPS database. Thus, we employ crime rate data from all 50 states plus the District of Columbia over the extended period 1978 to $2001 .^{16}$ This also allows us to employ a richer (both cross-sectionally and time-series) state bank branching measure since states adopted unrestricted branching throughout the 1970's, 80's, and 90's. Moreover, this provides an out of sample test of our hypothesis using new data from new regions and time periods.

The dependent variable in Panel B is the year-to-year change in crime (reported homicides and burglaries per capita) from year $t-1$ to year $t$, regressed on a post unrestricted branching indicator which takes on the value one if the state adopted unrestricted branching within the last five years. Other control regressors include the lagged annual change from year $t-2$ to year $t-1$ in state population, employment per capita, social services employees per capita, income, and imprisonment rate. We also employ the lagged annual change in the state abortion rate from 16 years ago (i.e., from $t-17$ to $t-16$ ) as an additional regressor. Due to data limitations, regressions that include the lagged abortion rate begin in 1987. Because we are interested in cross-sectional differences in changes in crime rates across states, we examine first differences in our regressions. Furthermore, because we focus on cross-sectional differences in differences, we run the regressions in the style of Fama and MacBeth (1973), where each year a cross-sectional regression (across the 51 states) is run and the time-series average of the yearly cross-sectional coefficient estimates and their associated time-series standard errors are calculated. This procedure ignores time-series variation, focusing exclusively on the cross-section. More importantly, standard errors are robust to cross-correlation in the residual (due to year or other effects). ${ }^{17}$

As Panel B of Table 8 indicates, the post state branching variable has a significant negative effect on burglary, with point estimates of small, though similar, magnitude to those obtained from our merger variable in the COMPS sample. The effect on homicide is negative, but statistically insignificant, as in our previous results. These findings, on a new data set, over a different sample period, across all states, and using a new exogenous measure of competition, bolster our contention that there is a link between credit market competitiveness, real activity, and crime.

\footnotetext{
${ }^{16}$ Although crime rate data go back to 1960 , many of the control variables we employ, such as state income and social services employees, date back only to 1977. Since we regress changes in crime on lagged changes in these variables, the sample starts in 1978.

${ }^{17}$ The Fama-MacBeth procedure produces conservative standard errors by allowing anything that drives variation in the year-to-year coefficient estimates to show up in the standard error. This effectively ignores any cross-sectional residual correlation from the yearly regressions, resulting in robust standard errors. For further detail regarding this method and its merits see Fama and MacBeth (1973) and Cochrane (2001).
} 


\section{Conclusion}

In this paper we provide evidence that the neighborhoods most affected by bank mergers subsequently experience significantly worse credit terms, less development and investment, lower real estate prices, an inflow of poorer households, and greater increases in property crime in subsequent years. These results are confirmed by our finding that state branching deregulation leads to more credit supply and less future property crime. Our results highlight that credit market imperfections can have important spillover effects on both economic and social outcomes.

These findings suggest that in evaluating the impact of bank mergers, regulators would do well to consider not only the present bank concentration of potentially affected markets, but also the social fragility of these markets. Neighborhoods that already suffer from low median incomes and poor loan competition experience greater increases in crime after a merger-induced reduction in banking competition. We do not argue that every bank merger has a negative impact on local credit conditions, but our results do suggest that it would be reasonable to apply greater scrutiny to mergers affecting low-income areas. Clearly, mergers per se are not uniformly bad, but in delicate and marginal areas they seem to have significant competitive effects that generate economic and social consequences.

We propose and provide evidence on one simple mechanism connecting crime and real activity to the market for finance, but a more general link between financial access, development, and social outcomes may be worth pursuing. If, as has been shown here and by others, inefficient loan markets retard development, then a range of economic and social issues including, for example, education and health care might be connected to the availability of finance. Future research may carefully

consider the broader role of competitive and well-functioning credit markets in fostering economic development and social harmony. 


\section{References}

Akhavein, Jalal D.,Allen N. Berger,and David Humphrey, "The Effects of Megamergers on Efficiency and Prices: Evidence from a Bank Profit Function," Review of Industrial Organization 12 (1997), 95-139.

Becker, Gary S., "Crime and Punishment: An Economic Approach," Journal of Political Economy 76 (1968), 169-217.

Berger, Allen N, Rebecca S. Demsetz, and Philip E. Strahan, "The Consolidation of the Financial Services Industry: Causes, Consequences, and Implications for the Future," Journal of Banking and Finance 23 (1999), 135-94.

Berger, Allen N., Seth D. Bonime, Lawrence G. Goldberg, and Lawrence J. White, "The Dynamics of Market Entry: The Effects of Mergers and Acquisitions on De Novo Entry and Small Business Lending in the Banking Industry," Federal Reserve Board Finance and Economics Discussion Series, 1999-41 (July).

Berger, Allen N., and Timothy H. Hannan, "The Price-Concentration Relationship in Banking," Review of Economics and Statistics 71 (1989), 291-99.

Berger, Allen N., Anthony Saunders, Joseph M. Scalise and Gregory Udell, "The effects of bank mergers and acquisitions on small business lending," Journal of Financial Economics 50 (1998), 187-229.

Black, Sandra E., and Philip E. Strahan, "Entrepreneurship and Bank Credit Availability," Journal of Finance 57 (2002), 2807-2834.

Burgess, Robin, and Rohini Pande, "Do Rural Banks Matter? Evidence from the Indian Social Banking Experiment," Working paper, London School of Economics, (2003).

Cetorelli, Nicola, and Michele Gambera, "Banking Market Structure, Financial Dependence and Growth: International Evidence from Industry Data," Journal of Finance 56 (2001), 617-648.

Chiricos, Theodore, "Rates of crime and unemployment: an analysis of aggregate research evidence," Social Problems 34 (1987), 187-211.

Cochrane, John H., "Asset Pricing," Princeton University Press (2001).

Cragg, J., 1971, "Some Statistical Models for Limited Dependent Variables with Application to the Demand for Durable Goods," Econometrica, 39 , 829-844.

Cullen, Julie, and Steven Levitt, "Crime, Urban Flight, and the Consequences for Cities," Review of Economics and Statistics 81 (1999), 159-169.

Demirguc-Kunt, Asli, and Vojislav Maksimovic, "Law, Finance, and Firm Growth," Journal of Finance 53 (1998), 2107-2137.

Donohue, John J., and Steven Levitt, "The Impact of Legalized Abortion on Crime," Quarterly Journal of Economics, 116 (2001), 379-420.

Ehrlich, Isaac, "Participation in illegitimate activities: a theoretical and empirical investigation," Journal of Political Economy, 81 (1973), 521-565.

Fajnzylber, Pablo, Daniel Lederman and Norman Loayza, "Inequality and Violent Crime," Journal of Law and Economics, 45 (2002), 1-40.

Fama, E.F., MacBeth, J., 1973. Risk, return, and equilibrium: Empirical tests. Journal of Political Economy 71, 607-636.

Federal Deposit Insurance Corporation, History of the Eighties - Lessons for the Future, 1997. 
Freeman, Richard B., "The supply of youths to crime," in Susan Pozo, ed., Exploring the underground economy (W.E. Upjohn Institute for Employment Research, Kalamazoo, MI) Chapter 3 (1996).

Freeman, Richard B., "The Economics of Crime," in O. Ashenfelter and D. Card, eds., Handbook of Labor Economics, vol. 3, 1999, Elsevier Science, Amsterdam.

Freeman, Richard B., and William M. Rodgers, "Area Economic Conditions and the Labor Market Outcomes of Young Men in the 1990s Expansion," NBER Working Paper 7073, (1999).

Garmaise, Mark J., and Tobias J. Moskowitz, "Informal Financial Networks: Theory and Evidence," Review of Financial Studies, Vol. 16 No. 4, 1007-1040 (2003).

Garmaise, M., and T. Moskowitz, "Confronting Information Asymmetries: Evidence from Real Estate Markets," Review of Financial Studies, Vol. 17 No. 2, 405-437 (2004).

Glaeser, E., B. Sacerdote, and J. Scheinkman, "Crime and social interactions," Quarterly Journal of Economics (1996), 61 (2), 507-548.

Glaeser, E., B. Sacerdote, and J. Scheinkman, "The social multiplier," NBER working paper no. 9153 (2002).

Gould, Eric, Bruce Weinberg, and David Mustard, "Crime Rates and Local Labor Market Opportunities in the United States: 1979-1997," The Review of Economics and Statistics, 84(2002), 45-61.

Grogger, Jeff, "Market Wages and Youth Crime," Journal of Labor Economics, 16 (1998), 756-791. Gyourko, Joseph, and Joseph Tracy, "The Structure of Local Public Finance and the Quality of Life," Journal of Political Economy, 99 (1991), 774-806.

Hancock, Diane, and James A. Wilcox, "Bank Capital, Nonbank Finance, and Real Estate Activity," Journal of Housing Research, 8 (1997), 75-105.

Hannan, Timothy H., "Market Share Inequality, the Number of Competitors, and the HHI: An Examination of Bank Pricing," Review of Industrial Organization, 12 (1997), 23-35.

Houston, Joel F., and Michael D. Ryngaert, "The Overall Gains from Large Bank Mergers," Journal of Banking and Finance, 18 (1994), 1155-76.

Jayaratne, Jith, and Philip Strahan, "The Finance-Growth Nexus: Evidence from Bank Branch Deregulation," Quarterly Journal of Economics, 111 (1996), 639-670.

Kelly, Morgan, "Inequality and Crime," Review of Economics and Statistics, 82 (2000), 530-539.

King, Robert, and Ross Levine, "Finance and Growth: Schumpeter Might Be Right," Quarterly Journal of Economics, 108 (1993), 717-737.

Klein, Michael, Joe Peek and Eric Rosengren, "Troubled Banks, Impaired Foreign Investment: The Role of Relative Access to Credit," American Economic Review, 92 (2002), 664-682.

Kwast, Myron L., Martha Starr-McCluer, and John D. Wolken, "Market Definition and the Analysis of Antitrust in Banking," Antitrust Bulletin 42 (1997), 973-95.

Land, Kenneth, Patrica McCall, and Lawrence Cohen, "Structural Covariates of Homicide Rates: Are There Any Invariances Across Time and Social Space," American Journal of Sociology, 95 (1990), 922-963.

Levitt, Steven D., "The Effect of Prison Population Size on Crime Rates: Evidence from Prison Overcrowding Litigation," Quarterly Journal of Economics, Vol. 111, (1996), 319-352.

Levitt, Steven D., "Juvenile Crime and Punishment," Journal of Political Economy, Vol. 106, No. 6. (1998), pp. 1156-1185. 
Levitt, Steven D., "The Exaggerated Role of Changing Age Structure in Explaining Aggregate Crime Changes," Criminology, Vol. 37, (August 1999), 581-599.

Levitt, Steven D., "Alternative Strategies for Identifying the Link Between Unemployment and Crime," Journal of Quantitative Criminology, Vol. 17, No. 4. (2001), pp. 377-390.

Nilsson, Anna, "Income inequality and crime: The case of Sweden," Working paper, Institute for Labour Market Policy Evaluation, (2004).

Pace, R. Kelley, Ronald Barry and C.F. Sirmans, "Spatial Statistics and Real Estate," Journal of Real Estate Finance and Economics, Vol. 17, No. 1 (1998), 5-13.

Peek, Joe, and Eric Rosengren, "Small Business Credit Availability: How Important is Size of Lender," in A. Saunders and I. Walter, eds., Financial System Design: The Case for Universal Banking, 1996, Irwin, Burr Ridge, Ill.

Peek, Joe, and Eric Rosengren, "Bank Regulatory Agreements and Real Estate Lending," Real Estate Economics 24 (1996), 55-173.

Peek, Joe, and Eric Rosengren, "Bank Consolidation and Small Business Lending: It's Not Just the Bank Size that Matters," Journal of Banking and Finance 22 (1998), 799-820.

Peek, Joe, and Eric Rosengren, "Collateral Damage: Effects of the Japanese Bank Crisis on Real Activity in the United States," American Economic Review 90 (2000), 30-45.

Petersen, Mitchell and Raghuram Rajan, 2002, "Does Distance Still Matter? The Information Revolution in Small Business Lending," Journal of Finance 57 (6), 2533-2570.

Prager, Robin A., and Timothy Hannan, "Do Substantial Horizontal Mergers Generate Significant Price Effects? Evidence from the Banking Industry," Journal of Industrial Economics 46 (1998), 433-52.

Rajan, Raghuram, and Luigi Zingales, "Financial Dependence and Growth," American Economic Review 88 (1998), 559-586.

Raphael, S. and R. Winter-Ebmer "Identifying the effect of unemployment on crime," Journal of Law and Economics 44 (2001), 259283.

Rhoades, Stephen, "Bank Mergers and Banking Structure in the U.S., 1980-1998," Staff Study 174 of the Board of Governors of the Federal Reserve System (Aug. 2000), 1-33.

Rickman, Neil and Robert Witt, "The determinants of employee crime in the UK," Working Paper, University of Surrey, 2003.

Sapienza, Paola, "The Effects of Banking Mergers on Loan Contracts," Journal of Finance 47 (2002), 329-367.

Strahan, Phillip, and James Weston, "Small Business Lending and the Changing Structure of the Banking Industry," Journal of Banking and Finance 22 (1998), 821-845.

Thaler, Richard, "A Note on the Value of Crime Control: Evidence from the Property Market," Journal of Urban Economics 5 (1978), 137-45.

Walraven, Nicholas, "Small Business Lending by Banks Involved in Mergers," Board of Governors of the Federal Reserve System, Finance and Economics Discussion Paper Series (May 1997). 


\section{Appendix A: Examples of Mergers Included and Excluded from the Competition Measure}

Table A1 presents examples of the bank and bank holding company mergers included and excluded from our measure of the predicted change in bank loan concentration through mergers. Only mergers between non-failing banks or bank holding companies with at least $\$ 1$ billion in assets are included in our competition measure. Two examples of bank mergers included in our measure are provided along with two examples each of bank mergers excluded from our measure due to failure (requiring assistance from either the FDIC, RTC, NCUA, state or other regulatory agency), mergers within the same holding company, or assets less than $\$ 1$ billion.

Table A1:

Examples of Mergers Included and Excluded from the Competition Measure

\begin{tabular}{|c|c|c|c|c|c|c|c|}
\hline & Acquirer & Target & $\begin{array}{l}\text { Type of } \\
\text { Union }\end{array}$ & Date & $\begin{array}{l}\text { New } \\
\text { Name }\end{array}$ & $\begin{array}{l}\text { Included? } \\
\text { Excluded? }\end{array}$ & Reason \\
\hline (1) & $\begin{array}{l}\text { National Bank } \\
\text { of Detroit }\end{array}$ & $\begin{array}{l}\text { The First National } \\
\text { Bank of Chicago }\end{array}$ & $\begin{array}{l}\text { Holding Company } \\
\text { Acquisition }\end{array}$ & Dec., 1995 & $\begin{array}{l}\text { First Chicago } \\
\text { NBD Corp. }\end{array}$ & Included & Met all criteria \\
\hline$(2)$ & $\begin{array}{l}\text { Wells } \\
\text { Fargo Bank }\end{array}$ & $\begin{array}{l}\text { First Inter- } \\
\text { state Bankcorp }\end{array}$ & Merger & Apr.-Jun., 1996 & $\begin{array}{l}\text { Wells } \\
\text { Fargo Bank }\end{array}$ & Included & Met all criteria \\
\hline (3) & $\begin{array}{l}\text { California } \\
\text { Federal Bank }\end{array}$ & $\begin{array}{l}\text { Pacific } \\
\text { Heritage Bank }\end{array}$ & Merger & July, 1995 & $\begin{array}{l}\text { California } \\
\text { Federal Bank }\end{array}$ & Excluded & $\begin{array}{l}\text { Required } \\
\text { assistance (failure) }\end{array}$ \\
\hline (4) & $\begin{array}{l}\text { Union } \\
\text { Bank }\end{array}$ & $\begin{array}{l}\text { Bank of } \\
\text { Newport }\end{array}$ & Merger & August, 1994 & $\begin{array}{l}\text { Union } \\
\text { Bank }\end{array}$ & Excluded & $\begin{array}{l}\text { Required } \\
\text { assistance (failure) }\end{array}$ \\
\hline (5) & $\begin{array}{l}\text { The Bank of } \\
\text { San Diego }\end{array}$ & $\begin{array}{l}\text { Coast } \\
\text { Bank }\end{array}$ & Merger & Dec., 1992 & $\begin{array}{l}\text { The Bank of } \\
\text { San Diego }\end{array}$ & Excluded & $\begin{array}{l}\text { Same Holding } \\
\text { Company }\end{array}$ \\
\hline (6) & $\begin{array}{l}\text { Corus } \\
\text { Bank }\end{array}$ & $\begin{array}{l}\text { Lincoln } \\
\text { National Bank }\end{array}$ & Merger & June, 1996 & $\begin{array}{l}\text { Corus } \\
\text { Bank }\end{array}$ & Excluded & $\begin{array}{l}\text { Same Holding } \\
\text { Company }\end{array}$ \\
\hline$(7)$ & $\begin{array}{l}\text { Mountain Parks } \\
\text { Bank - East }\end{array}$ & $\begin{array}{l}\text { The Kiowa } \\
\text { State Bank }\end{array}$ & Merger & Aug., 1996 & $\begin{array}{l}\text { Mountain Parks } \\
\text { Bank - East }\end{array}$ & Excluded & $\begin{array}{l}\text { Acquired bank had } \\
\$ 41 \text { million in assets }\end{array}$ \\
\hline (8) & US Trust & $\begin{array}{l}\text { Somerset } \\
\text { Savings Bank }\end{array}$ & Merger & July, 1998 & US Trust & Excluded & $\begin{array}{l}\text { Acquired bank had } \\
\$ 533 \text { million in assets }\end{array}$ \\
\hline
\end{tabular}




\section{Table 1: \\ Summary Statistics of Bank Mergers, Commercial Real Estate Transactions, and Crime Risk in the U.S. from 1992 to 1999}

Panel A reports the distributional characteristics of the property transactions in the COMPS database over the period January 1 , 1992 to March 30, 1999. The mean, median, standard deviation, and one and 99 percentiles of sale price, capitalization rate (net operating income divided by sales price), property age, loan size (loan-to-value), loan interest rate, and loan maturity are reported. Panel B reports statistics on the banks making loans in the COMPS database and on bank merger and acquisition activity of those banks (obtained from the Federal Reserve's Commercial Bank and Bank Holding Company Merger Database and Call Report Database). Statistics are reported separately for large banks that have at least $\$ 1$ billion in assets. Mergers are documented separately for those between two large banks, those involving a failing bank (where one of the banks required assistance from the FDIC, RTC, NCUA, state, or other regulatory agencies), and for banks within the same bank holding company (BHC). These three classes of mergers are mutually exclusive. The mean and standard deviation of the actual Herfindahl concentration index of commercial real estate bank loans (from all banks) within 15 miles of the property (excluding the property itself) from year $y r_{1}$ to year $y_{2}$ are also reported. Panel C reports local crime risk scores at three points in time $(1990,1995$, and 2000) for crimes against person (homicide) and property (burglary) for the location in which the property resides. Crime scores relative to their national and county averages are obtained from CAP Index, Inc. Correlations between the Cap Index crime risks and the FBI's Uniform Crime Report (UCR) crime rates (reported number of crimes per capita) are also reported.

\begin{tabular}{|c|c|c|c|c|c|}
\hline \multicolumn{6}{|c|}{ Panel A: Summary statistics of sale and loan transactions } \\
\hline & Mean & Median & $\begin{array}{l}\text { Standard } \\
\text { deviation }\end{array}$ & $1^{\text {st }} \%$ & $99^{t h} \%$ \\
\hline Sale price $(\$ U S)$ & $2,387,000$ & 600,000 & $10,481,000$ & 110,000 & $27,000,000$ \\
\hline Capitalization rate (percent) & 10.09 & 9.82 & 2.79 & 4.64 & 17.27 \\
\hline Property age (years) & 35.55 & 30.00 & 30.53 & 1 & 106 \\
\hline Loan size (\% of price) & 75.83 & 77.77 & 15.99 & 20.00 & 100.00 \\
\hline Interest rate (percent) & 8.28 & 8.25 & 1.40 & 5 & 11.75 \\
\hline Maturity (years) & 15.95 & 15.00 & 10.74 & 0.50 & 30.00 \\
\hline
\end{tabular}

\begin{tabular}{|c|c|c|c|c|c|c|}
\hline \multicolumn{7}{|c|}{ Panel B: Bank merger and acquisition activity } \\
\hline & & All banks & \multicolumn{3}{|c|}{ Large banks ( $>\$ 1$ billion in assets) } & \\
\hline \multicolumn{2}{|l|}{ \# Banks } & 769 & 210 & & & \\
\hline \multicolumn{2}{|l|}{ \# Loans made } & 8,364 & 5,092 & & & \\
\hline \multicolumn{2}{|l|}{ Value of loans made (\$bill.) } & $\$ 9.8211$ & $\$ 7.3092$ & & & \\
\hline \multicolumn{2}{|l|}{ Minimum loan value } & $\$ 1,318$ & $\$ 1,318$ & & & \\
\hline \multicolumn{2}{|l|}{ Average loan value } & $\$ 1,174,630$ & $\$ 1,435,720$ & & & \\
\hline \multicolumn{2}{|l|}{ Maximum loan value } & $\$ 220$ million & $\$ 220$ million & & & \\
\hline \multicolumn{2}{|l|}{ Average value of property } & $\$ 1,616,450$ & $\$ 1,986,632$ & & & \\
\hline \multicolumn{2}{|l|}{ \# States made loans to } & 12 & 12 & & & \\
\hline \multicolumn{2}{|l|}{ \# Counties made loans to } & 42 & 38 & & & \\
\hline \multicolumn{2}{|l|}{ \# Zip codes made loans to } & 1,028 & 881 & & & \\
\hline & & All & Large & Failing & Same BHC & \\
\hline \multicolumn{2}{|l|}{ \# Bank mergers and acquisitions } & 316 & 80 & 18 & 75 & \\
\hline & & \multicolumn{5}{|c|}{ Actual level of bank concentration: BankHI $I^{\text {actual level }}$} \\
\hline & & $1992: 1995$ & 1992 : saleyear & $1992: 1999$ & & \\
\hline \multicolumn{2}{|l|}{ Mean } & 0.0526 & 0.0576 & 0.0589 & & \\
\hline \multicolumn{2}{|l|}{ Standard deviation } & 0.0273 & 0.0291 & 0.0310 & & \\
\hline \multicolumn{7}{|c|}{ Panel C: Summary statistics of crime risk from Cap Index, Inc. } \\
\hline & \multicolumn{3}{|c|}{ Relative to National Average } & \multicolumn{3}{|c|}{ Relative to County Average } \\
\hline & Mean & $\begin{array}{l}\text { Standard } \\
\text { deviation }\end{array}$ & $\begin{array}{c}\text { Correlation } \\
\text { with UCR }\end{array}$ & Mean & $\begin{array}{l}\text { Standard } \\
\text { deviation }\end{array}$ & $\begin{array}{l}\text { Correlation } \\
\text { with UCR }\end{array}$ \\
\hline Homicide risk 1990 & 1.95 & 1.85 & 0.33 & 1.49 & 1.06 & -0.11 \\
\hline Homicide risk $_{1995}$ & 2.01 & 1.97 & 0.38 & 1.51 & 1.10 & -0.12 \\
\hline Homicide risk 2000 & 2.02 & 1.95 & 0.37 & 1.52 & 1.09 & -0.11 \\
\hline Burglary risk 1990 & 3.32 & 3.55 & 0.58 & 1.80 & 1.25 & -0.05 \\
\hline Burglary risk 1995 & 3.04 & 3.04 & 0.56 & 1.81 & 1.15 & -0.05 \\
\hline Burglary risk 2000 & 2.94 & 2.90 & 0.56 & 1.80 & 1.10 & -0.05 \\
\hline
\end{tabular}


Table 2:

The Impact of Bank Mergers on Competition, Loan Rates, and Borrowing Activity

The actual change in bank loan concentration, loan rate, loan frequency, and loan size are regressed on predictive measures of changing local bank competition through various sets of mergers, $\Delta B a n k H I_{y r_{1}: y r_{2}}$, which is the sum of the individual year differences between the actual Herfindahl concentration index of commercial loans within 15 miles of a property and the hypothetical concentration index assuming all bank mergers took place at the beginning of each year. Salyear is the year in which the property sold. All regressions include the current property crime risk (1995), recent change in property crime (from 1990 to 1995), local price variation, which is the cross-sectional variation of capitalization rates on properties within 15 miles, and recent growth in population, per capita income, and median home value for the census tract (from the 1990 to 2000 Census). Loan interest rate regressions also include the loan-to-value ratio, an indicator for floating rates and SBA-backed loans, and length of amortization and maturity. A constant and fixed effects for property type, year, and county are included in all regressions. Loan term regressions also include bank fixed effects. Coefficient estimates and their associated $t$-statistics (in parentheses) are reported with robust standard errors that assume group-wise clustering at the zip code level. Panel A employs mergers between all non-failing banks and bank holding companies with at least $\$ 1$ billion in assets. For the same set of mergers, Panel B employs a value-weighted concentration measure, Panel C examines only those deals in 1998 and 1999, and Panel D examines property deals worth at least $\$ 10$ million. Panel E employs mergers between banks within the same bank holding company (BHC) and Panel F employs mergers between banks where at least one bank is failing, requiring assistance from the FDIC, RTC, NCUA, state, or other regulatory agency.

\begin{tabular}{|c|c|c|c|c|}
\hline \multicolumn{5}{|c|}{ Panel A: Mergers between large (assets $>\$ 1$ billion) banks and bank holding companies } \\
\hline & $(1)$ & $(2)$ & $(3)$ & $(4)$ \\
\hline Dependent & Actual & Loan & Loan & Loan \\
\hline variable $=$ & $\Delta B a n k H I$ & rate & frequency & size \\
\hline$\Delta$ BankHI $I_{1992: 1995}$ & $\begin{array}{c}0.7802 \\
(5.21)\end{array}$ & & & \\
\hline$\Delta$ BankHI $I_{1992: \text { saleyear }}$ & & $\begin{array}{c}32.9045 \\
(3.30)\end{array}$ & $\begin{array}{c}-2.0473 \\
(-1.60)\end{array}$ & $\begin{array}{c}-2.2018 \\
(-2.81)\end{array}$ \\
\hline Crime $_{1995}$ & $\begin{array}{c}-0.0012 \\
(-1.30)\end{array}$ & $\begin{array}{c}0.0004 \\
(2.37)\end{array}$ & $\begin{array}{l}0.0001 \\
(3.47)\end{array}$ & $\begin{array}{c}0.0001 \\
(5.28)\end{array}$ \\
\hline$\% \Delta$ Crime $_{1990: 1995}$ & $\begin{array}{c}0.0036 \\
(0.65)\end{array}$ & $\begin{array}{c}-0.0812 \\
(-0.45)\end{array}$ & $\begin{array}{c}-0.0036 \\
(-0.15)\end{array}$ & $\begin{array}{c}-0.0111 \\
(-0.61)\end{array}$ \\
\hline Price variation & $\begin{array}{c}-0.0015 \\
(-1.52)\end{array}$ & $\begin{array}{c}0.2224 \\
(1.96)\end{array}$ & $\begin{array}{c}0.0303 \\
(1.97)\end{array}$ & $\begin{array}{c}0.0032 \\
(0.41)\end{array}$ \\
\hline Population growth & $\begin{array}{c}-0.0001 \\
(-0.90)\end{array}$ & $\begin{array}{c}0.0145 \\
(1.15)\end{array}$ & $\begin{array}{c}-0.0001 \\
(-0.07)\end{array}$ & $\begin{array}{c}0.0001 \\
(0.26)\end{array}$ \\
\hline Income growth & $\begin{array}{c}0.0003 \\
(12.88)\end{array}$ & $\begin{array}{c}-0.0108 \\
(-2.05)\end{array}$ & $\begin{array}{c}-0.0002 \\
(-0.61)\end{array}$ & $\begin{array}{c}0.0001 \\
(0.23)\end{array}$ \\
\hline Home value growth & $\begin{array}{r}-0.0007 \\
(-2.80)\end{array}$ & $\begin{array}{c}0.0158 \\
(0.75)\end{array}$ & $\begin{array}{c}-0.0021 \\
(-0.75)\end{array}$ & $\begin{array}{c}0.0002 \\
(0.10)\end{array}$ \\
\hline Loan-to-value & & $\begin{array}{c}0.1014 \\
(0.56)\end{array}$ & & \\
\hline Floating & & $\begin{array}{l}-1.2284 \\
(-15.97)\end{array}$ & & \\
\hline Amortization & & $\begin{array}{r}-0.0077 \\
(-3.03)\end{array}$ & & \\
\hline Maturity & & $\begin{array}{c}-0.0186 \\
(-5.72)\end{array}$ & & \\
\hline SBA & & $\begin{array}{c}0.7035 \\
(1.44)\end{array}$ & & \\
\hline Fixed effects: & & & & \\
\hline Year & No & Yes & Yes & Yes \\
\hline Property type & Yes & Yes & Yes & Yes \\
\hline County & Yes & Yes & Yes & Yes \\
\hline Bank & No & Yes & Yes & Yes \\
\hline Adj. $R^{2}$ & 0.94 & 0.30 & 0.01 & 0.03 \\
\hline$N$ & 22,317 & 6,267 & 16,131 & 16,131 \\
\hline$N$ cluster & 1,147 & 915 & 1,162 & 1,162 \\
\hline
\end{tabular}




\begin{tabular}{|c|c|c|c|c|}
\hline \multicolumn{5}{|c|}{ Panel B: Value (\$) weighted concentration measures } \\
\hline & (1) & $(2)$ & $(3)$ & $(4)$ \\
\hline Dependent & Actual & Loan & Loan & Loan \\
\hline variable $=$ & $\Delta B a n k H I$ & rate & frequency & size \\
\hline$\Delta B a n k H I_{1992: 1995}$ & $\begin{array}{c}0.6206 \\
(3.03)\end{array}$ & & & \\
\hline$\Delta$ BankH $I_{1992: \text { saleyear }}$ & & $\begin{array}{c}31.8839 \\
(3.63)\end{array}$ & $\begin{array}{c}-1.9255 \\
(-1.69)\end{array}$ & $\begin{array}{c}-2.0652 \\
(-2.95)\end{array}$ \\
\hline Adj. $R^{2}$ & 0.91 & 0.30 & 0.01 & 0.03 \\
\hline$N$ & 22,317 & 6,267 & 16,131 & 16,131 \\
\hline \multicolumn{5}{|c|}{ Panel C: Only deals from 1998 and 1999} \\
\hline & $(1)$ & $(2)$ & $(3)$ & $(4)$ \\
\hline $\begin{array}{l}\text { Dependent } \\
\text { variable = }\end{array}$ & $\begin{array}{c}\text { Actual } \\
\Delta B a n k H I\end{array}$ & $\begin{array}{l}\text { Loan } \\
\text { rate }\end{array}$ & $\begin{array}{c}\text { Loan } \\
\text { frequency }\end{array}$ & $\begin{array}{l}\text { Loan } \\
\text { size }\end{array}$ \\
\hline$\Delta B a n k H I_{1992: 1994}$ & $\begin{array}{c}-5.7718 \\
(-2.54)\end{array}$ & $\begin{array}{c}27.4350 \\
(0.54)\end{array}$ & $\begin{array}{l}6.8218 \\
(1.21)\end{array}$ & $\begin{array}{c}1.0305 \\
(0.33)\end{array}$ \\
\hline$\Delta B a n k H I_{1995: 1997}$ & $\begin{array}{l}2.8548 \\
(2.45) \\
\end{array}$ & $\begin{array}{c}30.1367 \\
(2.75) \\
\end{array}$ & $\begin{array}{c}-2.7793 \\
(-1.82) \\
\end{array}$ & $\begin{array}{c}-2.3124 \\
(-2.48)\end{array}$ \\
\hline Adj. $R^{2}$ & 0.79 & 0.30 & 0.01 & 0.03 \\
\hline$N$ & 3,299 & 899 & 3,282 & 3,282 \\
\hline \multicolumn{5}{|c|}{ Panel D: Deals $>\$ 10$ million, not likely affected by local competition } \\
\hline & (1) & $(2)$ & (3) & (4) \\
\hline $\begin{array}{l}\text { Dependent } \\
\text { variable = }\end{array}$ & & $\begin{array}{l}\text { Loan } \\
\text { rate }\end{array}$ & $\begin{array}{c}\text { Loan } \\
\text { frequency }\end{array}$ & $\begin{array}{c}\text { Loan } \\
\text { size }\end{array}$ \\
\hline$\Delta B a n k H I_{1992: \text { saleyear }}$ & & $\begin{array}{c}-9.1930 \\
(-0.19)\end{array}$ & $\begin{array}{l}-2.1470 \\
(-0.43)\end{array}$ & $\begin{array}{c}-1.4040 \\
(-0.51)\end{array}$ \\
\hline Adj. $R^{2}$ & & 0.15 & 0.01 & 0.01 \\
\hline$N$ & & 94 & 471 & 471 \\
\hline \multicolumn{5}{|c|}{ Panel E: Mergers within the same BHC } \\
\hline & (1) & (2) & (3) & (4) \\
\hline $\begin{array}{l}\text { Dependent } \\
\text { variable = }\end{array}$ & $\begin{array}{c}\text { Actual } \\
\Delta B a n k H I\end{array}$ & $\begin{array}{l}\text { Loan } \\
\text { rate }\end{array}$ & $\begin{array}{c}\text { Loan } \\
\text { frequency }\end{array}$ & $\begin{array}{l}\text { Loan } \\
\text { size }\end{array}$ \\
\hline$\Delta B a n k H I_{1992: 1995}$ & $\begin{array}{l}-0.1990 \\
(-0.28)\end{array}$ & & & \\
\hline$\Delta$ BankH $I_{1992: \text { saleyear }}$ & & $\begin{array}{c}5.7310 \\
(0.95) \\
\end{array}$ & $\begin{array}{c}-0.6327 \\
(-0.28) \\
\end{array}$ & $\begin{array}{c}-0.1624 \\
(-0.11) \\
\end{array}$ \\
\hline Adj. $R^{2}$ & 0.79 & 0.29 & 0.01 & 0.03 \\
\hline$N$ & 22,633 & 6,267 & 16,131 & 16,131 \\
\hline \multicolumn{5}{|c|}{ Panel F: Mergers of failing banks } \\
\hline & $(1)$ & $(2)$ & (3) & (4) \\
\hline $\begin{array}{l}\text { Dependent } \\
\text { variable = }\end{array}$ & $\begin{array}{c}\text { Actual } \\
\Delta B a n k H I\end{array}$ & $\begin{array}{l}\text { Loan } \\
\text { rate }\end{array}$ & $\begin{array}{c}\text { Loan } \\
\text { frequency }\end{array}$ & $\begin{array}{l}\text { Loan } \\
\text { size }\end{array}$ \\
\hline$\Delta B a n k H I_{1992: 1995}$ & $\begin{array}{l}6.8415 \\
(1.82)\end{array}$ & & & \\
\hline$\Delta$ BankH $I_{1992: \text { saleyear }}$ & & $\begin{array}{c}13.3604 \\
(1.33)\end{array}$ & $\begin{array}{c}185.0766 \\
(1.25)\end{array}$ & $\begin{array}{c}30.1756 \\
(0.37)\end{array}$ \\
\hline Adj. $R^{2}$ & 0.81 & 0.30 & 0.01 & 0.03 \\
\hline$N$ & 22,615 & 6,267 & 16,131 & 16,131 \\
\hline
\end{tabular}


Table 3:

The Impact of Bank Competition (through Mergers) on the Local Economy

Panel A reports regression results of real investment proxies and property cap rates on predicted changes in local bank competition measured through mergers. Panel B reports regression results of percentage changes from 1990 to 2000 in census tract level median income, income migration (the ratio of income of households who moved into the tract within the last five years over the income of households who have resided in the tract at least five years), unemployment, income dispersion (defined as the standard deviation of the fraction of households in the eight census income categories), and rental and vacancy rates on predicted changes in local bank competition measured through mergers. Predicted changes in local bank competition are measured as described in Figure 1 and Table 2. All regressions include a constant, current property crime risk (1995), recent growth in property crime (from 1990 to 1995), local price variation, recent growth in population, income, and home value for the census tract, and property type and county fixed effects, which are omitted from the table for brevity. The cap rate regression also includes year fixed effects. Coefficient estimates and their associated $t$-statistics (in parentheses) are reported with robust standard errors that assume group-wise clustering at the zip code level for cap rate and age regressions and at the census tract level for the census statistics regressions.

\begin{tabular}{|c|c|c|c|c|c|}
\hline \multicolumn{6}{|c|}{ Panel A: Investment, development, and prices } \\
\hline \multirow[b]{3}{*}{ Dependent variable $=$} & & (1) & $(2)$ & (3) & \\
\hline & & $\Delta$ Mean & $\Delta \%$ Age $<$ & Cap rate & \\
\hline & & age & 3 years & $(\mathrm{E} / \mathrm{P})$ & \\
\hline \multicolumn{2}{|l|}{$\Delta$ BankH $I_{1992: \text { saleyear }}$} & & & $\begin{array}{l}8.2347 \\
(3.73)\end{array}$ & \\
\hline \multicolumn{2}{|l|}{$\Delta$ BankH $I_{1992: 1995}$} & $\begin{array}{c}268.1843 \\
(3.67)\end{array}$ & $\begin{array}{c}-0.3286 \\
(-3.41)\end{array}$ & & \\
\hline \multicolumn{6}{|l|}{ Fixed effects: } \\
\hline \multicolumn{2}{|l|}{ Year } & No & No & Yes & \\
\hline \multicolumn{2}{|l|}{ Property type } & Yes & Yes & Yes & \\
\hline \multicolumn{2}{|l|}{ County } & Yes & Yes & Yes & \\
\hline \multicolumn{2}{|l|}{ Adj. $R^{2}$} & 0.84 & 0.76 & 0.24 & \\
\hline \multicolumn{2}{|l|}{$N$} & 15,734 & 15,734 & 10,070 & \\
\hline \multicolumn{2}{|l|}{$N$ cluster } & 873 & 873 & 978 & \\
\hline \multicolumn{6}{|c|}{ Panel B: Income distribution, unemployment, and vacancy } \\
\hline \multirow[b]{2}{*}{ Dependent variable $=$} & $(1)$ & $(2)$ & $(3)$ & $(4)$ & $(5)$ \\
\hline & $\begin{array}{l}\% \Delta \text { Median } \\
\text { income }\end{array}$ & $\begin{array}{l}\text { Income } \\
\text { migration }\end{array}$ & $\Delta$ Unemployment & $\begin{array}{l}\Delta \text { Income } \\
\text { dispersion }\end{array}$ & $\begin{array}{l}\Delta \text { Vacancy } \\
\text { and rental }\end{array}$ \\
\hline$\Delta$ BankH $I_{1992: 1995}$ & & $\begin{array}{c}-7.3931 \\
(-4.16)\end{array}$ & & & \\
\hline$\Delta B a n k H I_{1992: 1999}$ & $\begin{array}{c}-5.5486 \\
(-2.54)\end{array}$ & & $\begin{array}{c}10.3268 \\
(3.59)\end{array}$ & $\begin{array}{c}561.9380 \\
(2.87)\end{array}$ & $\begin{array}{l}41.7708 \\
(10.35)\end{array}$ \\
\hline \multicolumn{6}{|l|}{ Fixed effects: } \\
\hline Property type & Yes & Yes & Yes & Yes & Yes \\
\hline County & Yes & Yes & Yes & Yes & Yes \\
\hline Adj. $R^{2}$ & 0.22 & 0.11 & 0.25 & 0.02 & 0.43 \\
\hline$N$ & 16,910 & 9,343 & 16,154 & 17,763 & 16,900 \\
\hline$N$ cluster & 2,308 & 1,083 & 2,252 & 2,341 & 2,306 \\
\hline
\end{tabular}


Table 4:

\section{The Impact of Bank Competition (through Mergers) on Crime}

The percentage change in future crime risk from 1995 to 2000 for the eight digit latitude and longitude location in which each property resides is regressed on the predicted change in local bank competition induced by mergers from 1992 to 1995 , $\Delta$ BankHI 1992:1995, as defined in Figure 1 and Table 2. Crime risk variables come from Cap Index, Inc. and pertain to burglary, a property crime index which includes burglary, larceny, and motor vehicle theft, homicide, and a crime index for personal crimes which include homicide, rape, aggravated assault, and robbery. Panel A reports reduced form regression results of crime risk changes directly on the merger-predicted concentration variable. Panel B reports elasticity estimates by regressing the percentage change in future crime risk on the percentage change in BankHI induced by mergers. Panel $\mathrm{C}$ reports results from regressions that include interaction terms between $\Delta B a n k H I_{1992: 1995}$ and characteristics of the local market in which the property resides: the actual level of bank concentration from 1992 to 1995, dispersion in income within the census tract from the 1990 Census, level of crime in 1995, and median income in the census tract in 1990. All regressions include current crime risk (1995), recent growth in crime (from 1990 to 1995), local price variation, and recent growth in population, income, and home value for the census tract. A constant and property type and county fixed effects are also included. Coefficient estimates and their associated $t$-statistics (in parentheses) are reported with robust standard errors that assume group-wise clustering at the zip code level.

\begin{tabular}{|c|c|c|c|c|c|c|}
\hline \multicolumn{7}{|c|}{ Panel A: Dependent variable $=$ future change in crime risk \% $\Delta$ Crime $_{1995: 2000}$} \\
\hline \multirow{4}{*}{$\Delta$ BankH $I_{1992: 1995}$} & $(1)$ & $(2)$ & $(3)$ & $(4)$ & $(5)$ & (6) \\
\hline & Burglary & Property & Homicide & Personal & Burglary & Property \\
\hline & 0.3741 & 0.4377 & 0.3131 & -0.0196 & 0.3720 & 0.4404 \\
\hline & $(3.23)$ & $(2.95)$ & (1.12) & $(-0.12)$ & $(3.17)$ & $(2.95)$ \\
\hline \multirow[t]{2}{*}{ BankH $I_{1992-1995}^{\text {actual level }}$} & & & & & 0.0034 & -0.0045 \\
\hline & & & & & $(0.19)$ & $(-0.17)$ \\
\hline \multirow[t]{2}{*}{ Crime $_{1995}$} & -0.0001 & -0.0001 & -0.0001 & 0.0001 & -0.0001 & -0.0001 \\
\hline & $(-31.88)$ & $(-8.24)$ & $(-2.91)$ & $(5.03)$ & $(-31.45)$ & $(-8.28)$ \\
\hline \multirow[t]{2}{*}{$\% \Delta$ Crime $_{1990: 1995}$} & 0.2309 & 0.2586 & 0.0653 & 0.1864 & 0.2309 & 0.2586 \\
\hline & $(24.18)$ & $(18.90)$ & $(7.45)$ & $(13.74)$ & $(24.14)$ & $(18.90)$ \\
\hline \multirow[t]{2}{*}{ Price variation } & -0.0011 & -0.0044 & 0.0036 & 0.0023 & -0.0011 & -0.0044 \\
\hline & $(-2.44)$ & $(-2.37)$ & $(1.00)$ & $(1.52)$ & $(-2.49)$ & $(-2.37)$ \\
\hline \multirow{2}{*}{ Population growth } & -0.0001 & 0.0001 & 0.0002 & 0.0002 & -0.0001 & 0.0001 \\
\hline & $(-1.24)$ & $(0.73)$ & $(1.37)$ & $(1.49)$ & $(-1.24)$ & $(0.73)$ \\
\hline \multirow[t]{2}{*}{ Income growth } & 0.0001 & 0.0001 & 0.0001 & 0.0001 & 0.0001 & 0.0001 \\
\hline & $(4.15)$ & $(1.50)$ & $(1.44)$ & $(1.27)$ & $(4.15)$ & $(1.50)$ \\
\hline \multirow[t]{2}{*}{ Home value growth } & -0.0009 & -0.0021 & -0.0015 & 0.0001 & -0.0009 & -0.0021 \\
\hline & $(-5.17)$ & $(-4.79)$ & $(-2.73)$ & $(0.89)$ & $(-5.17)$ & $(-4.79)$ \\
\hline \multicolumn{7}{|l|}{ Fixed effects: } \\
\hline Property type & Yes & Yes & Yes & Yes & Yes & Yes \\
\hline County & Yes & Yes & Yes & Yes & Yes & Yes \\
\hline Adj. $R^{2}$ & 0.87 & 0.86 & 0.75 & 0.89 & 0.87 & 0.86 \\
\hline$N$ & 22,317 & 22,317 & 22,317 & 22,317 & 22,317 & 22,317 \\
\hline$N$ cluster & 1,146 & 1,146 & 1,146 & 1,146 & 1,146 & 1,146 \\
\hline \multicolumn{7}{|c|}{ Panel B: Elasticity estimates from percentage changes on percentage changes } \\
\hline \multirow{4}{*}{$\% \Delta B$ ank $H I_{1992: 1995}$} & & & (1) & $(2)$ & & \\
\hline & & & Burglary & Property & & \\
\hline & & & 0.1604 & 0.1842 & & \\
\hline & & & $(3.82)$ & $(4.36)$ & & \\
\hline \multicolumn{7}{|l|}{ Fixed effects: } \\
\hline Property type & & & Yes & Yes & & \\
\hline County & & & Yes & Yes & & \\
\hline Adj. $R^{2}$ & & & 0.88 & 0.86 & & \\
\hline$N$ & & & 22,317 & 22,317 & & \\
\hline$N$ cluster & & & 1,146 & 1,146 & & \\
\hline
\end{tabular}




\begin{tabular}{|c|c|c|c|c|c|c|c|c|c|c|}
\hline & \multicolumn{10}{|c|}{ Panel C: Interactions with local market characteristics } \\
\hline & $(1)$ & $(2)$ & $(3)$ & $(4)$ & $(5)$ & $(6)$ & $(7)$ & $(8)$ & (9) & $(10)$ \\
\hline & \multicolumn{5}{|c|}{ Burglary } & \multicolumn{5}{|c|}{ Property } \\
\hline$\Delta$ BankHI $I_{1992: 1995}$ & $\begin{array}{l}1.3403 \\
(2.98)\end{array}$ & $\begin{array}{c}-0.3715 \\
(-0.60)\end{array}$ & $\begin{array}{c}-1.1934 \\
(-3.05)\end{array}$ & $\begin{array}{l}1.0090 \\
(3.07)\end{array}$ & $\begin{array}{c}0.9838 \\
(1.62)\end{array}$ & $\begin{array}{c}2.1244 \\
(3.23)\end{array}$ & $\begin{array}{c}0.0040 \\
(0.01)\end{array}$ & $\begin{array}{l}0.0185 \\
(0.07)\end{array}$ & $\begin{array}{r}2.1587 \\
(3.99)\end{array}$ & $\begin{array}{l}4.0530 \\
(3.87)\end{array}$ \\
\hline$\times$ BankH $I_{1992-1995}^{\text {actual level }}$ & $\begin{array}{c}0.0010 \\
(1.82)\end{array}$ & & & & $\begin{array}{c}0.0031 \\
(1.83)\end{array}$ & $\begin{array}{c}0.0010 \\
(1.96)\end{array}$ & & & & $\begin{array}{c}0.0054 \\
(2.26)\end{array}$ \\
\hline $\begin{array}{l}\times \text { Income dispersion } \\
\text { in } 1990\end{array}$ & & $\begin{array}{c}21.0024 \\
(2.16)\end{array}$ & & & $\begin{array}{c}9.7015 \\
(0.57)\end{array}$ & & $\begin{array}{c}15.5402 \\
(2.52)\end{array}$ & & & $\begin{array}{r}-4.0742 \\
(-0.38)\end{array}$ \\
\hline $\begin{array}{l}\times \text { Crime level } \\
\text { in } 1995\end{array}$ & & & $\begin{array}{l}0.0095 \\
(4.54)\end{array}$ & & $\begin{array}{c}0.0005 \\
(0.28)\end{array}$ & & & $\begin{array}{c}0.0030 \\
(2.01)\end{array}$ & & $\begin{array}{l}0.0011 \\
(1.00)\end{array}$ \\
\hline $\begin{array}{l}\times \text { Median income } \\
\text { in } 1990\end{array}$ & & & & $\begin{array}{c}-0.0001 \\
(-2.36)\end{array}$ & $\begin{array}{l}-0.0001 \\
(-1.92)\end{array}$ & & & & $\begin{array}{l}-0.0001 \\
(-3.52)\end{array}$ & $\begin{array}{l}-0.0001 \\
(-3.47)\end{array}$ \\
\hline Fixed effects: & & & & & & & & & & \\
\hline Property type & Yes & Yes & Yes & Yes & Yes & Yes & Yes & Yes & Yes & Yes \\
\hline County & Yes & Yes & Yes & Yes & Yes & Yes & Yes & Yes & Yes & Yes \\
\hline Adj. $R^{2}$ & 0.89 & 0.88 & 0.88 & 0.88 & 0.88 & 0.86 & 0.86 & 0.86 & 0.86 & 0.86 \\
\hline$N$ & 22,317 & 22,317 & 22,317 & 22,317 & 22,317 & 22,317 & 22,317 & 22,317 & 22,317 & 22,317 \\
\hline$N$ cluster & 1,146 & 1,146 & 1,146 & 1,146 & 1,146 & 1,146 & 1,146 & 1,146 & 1,146 & 1,146 \\
\hline
\end{tabular}


Table 5:

\section{Does (Whatever Drives) Future Crime Spur Current Mergers?}

The first two columns of Panel A report results from regressions of the percentage change in the current crime risk from 1990 to 1995 on the contemporaneous bank merger variable for local bank concentration. Columns 3 and 4 report regression results of the actual future change in banking concentration from 1996 to 1999 on recent trends in crime risk, median income, and home value for the census tract. The first two (last two) columns of Panel B report regression results of the change in banking concentration due to mergers from 1996 to 1999 (probability of a merger) on recent trends in crime risk, median income, and home value. The first two (last two) columns of Panel C report results from regressions of future changes in crime from 1995 to 2000 on the predicted change in bank concentration due to mergers involving a failing bank (changes in the number of non-lending financial institutions from 1990 to 1995). Non-lending financial institutions are obtained from the County Business Patterns of the Bureau of Economic Analysis and are defined as the number of establishments with NAICS codes of 523, 524, and 525. All regressions include a constant, and the control variables from Table 4. Coefficient estimates and their associated $t$-statistics (in parentheses) are reported with robust standard errors that assume group-wise clustering at the zip code level for all regressions except those for non-lending financial institutions, which assume group-wise clustering at the county level.

\begin{tabular}{|c|c|c|c|c|}
\hline \multirow{4}{*}{$\begin{array}{l}\text { Panel A: } \\
\text { Dependent variable }=\end{array}$} & \multirow{2}{*}{\multicolumn{2}{|c|}{$\begin{array}{c}\text { Are crime and merger-induced bank } \\
\text { consolidation contemporaneously related? } \\
\% \Delta \text { Crime }_{1990: 1995}\end{array}$}} & \multirow{2}{*}{\multicolumn{2}{|c|}{$\begin{array}{c}\begin{array}{c}\text { Does crime or economic activity } \\
\text { predict future bank consolidation? }\end{array} \\
\Delta \text { BankH } I_{1996: 1999}^{\text {actual }}\end{array}$}} \\
\hline & & & & \\
\hline & (1) & $(2)$ & $(3)$ & $(4)$ \\
\hline & Burglary & Property & Burglary & Property \\
\hline$\Delta B a n k H I_{1992: 1995}$ & $\begin{array}{c}0.0398 \\
(0.20)\end{array}$ & $\begin{array}{c}-0.0432 \\
(-0.37)\end{array}$ & & \\
\hline$\% \Delta$ Crime $_{1990: 1995}$ & & & $\begin{array}{l}-0.0061 \\
(-0.35)\end{array}$ & $\begin{array}{c}-0.0346 \\
(-1.54)\end{array}$ \\
\hline Income growth & & & $\begin{array}{c}0.0005 \\
(0.47)\end{array}$ & $\begin{array}{c}0.0003 \\
(0.24)\end{array}$ \\
\hline Home value growth & & & $\begin{array}{l}-0.0006 \\
(-1.65)\end{array}$ & $\begin{array}{c}-0.0006 \\
(-1.92)\end{array}$ \\
\hline County fixed effects & Yes & Yes & Yes & Yes \\
\hline$N$ & 22,317 & 22,317 & 22,317 & 22,317 \\
\hline$N$ cluster & 1,146 & 1,146 & 1,146 & 1,146 \\
\hline Panel B: & \multicolumn{2}{|c|}{$\begin{array}{l}\text { Does crime or economic activity predict } \\
\text { bank consolidation due to mergers? }\end{array}$} & \multicolumn{2}{|c|}{$\begin{array}{l}\text { Does crime or economic activity } \\
\text { predict merger activity? }\end{array}$} \\
\hline \multirow[t]{3}{*}{ Dependent variable $=$} & \multicolumn{2}{|c|}{$\Delta$ BankHI $_{1996: 1999}$} & \multicolumn{2}{|c|}{ Probability of a merger } \\
\hline & $(1)$ & $(2)$ & $(3)$ & $(4)$ \\
\hline & Burglary & Property & Burglary & Property \\
\hline \multirow[t]{2}{*}{$\% \Delta$ Crime $_{1990: 1995}$} & -0.0008 & -0.0005 & -0.0935 & -0.0897 \\
\hline & $(-1.54)$ & $(-0.76)$ & $(-2.59)$ & $(-2.08)$ \\
\hline \multirow[t]{2}{*}{ Income growth } & 0.0001 & 0.0001 & 0.0058 & 0.0064 \\
\hline & $(0.98)$ & $(1.09)$ & $(0.65)$ & $(0.72)$ \\
\hline \multirow[t]{2}{*}{ Home value growth } & 0.0001 & 0.0001 & -0.0027 & -0.0025 \\
\hline & $(1.20)$ & $(1.24)$ & $(-0.74)$ & $(-0.70)$ \\
\hline County fixed effects & Yes & Yes & Yes & Yes \\
\hline$N$ & 22,317 & 22,317 & 22,317 & 22,317 \\
\hline$N$ cluster & 1,146 & 1,146 & 1,146 & 1,146 \\
\hline Panel C: & \multicolumn{2}{|c|}{$\begin{array}{l}\text { Do mergers of failing banks } \\
\text { predict future crime risk? }\end{array}$} & \multicolumn{2}{|c|}{$\begin{array}{l}\text { Do changes in \#non-lending financial } \\
\text { institutions predict crime risk? }\end{array}$} \\
\hline \multirow{3}{*}{ Dependent variable $=$} & \multicolumn{2}{|c|}{$\% \Delta$ Crime $_{1995: 2000}$} & \multicolumn{2}{|c|}{$\% \Delta$ Crime $_{1995: 2000}$} \\
\hline & (1) & $(2)$ & $(3)$ & $(4)$ \\
\hline & Burglary & Property & Burglary & Property \\
\hline$\Delta$ BankHI $I_{1992: 1995}^{\text {failing }}$ & $\begin{array}{l}0.2750 \\
(0.98)\end{array}$ & $\begin{array}{c}-0.3223 \\
(-1.87)\end{array}$ & & \\
\hline$\Delta$ Non-lending $1990: 1995$ & & & $\begin{array}{c}-0.0006 \\
(-0.24)\end{array}$ & $\begin{array}{l}-0.0186 \\
(-1.51)\end{array}$ \\
\hline County fixed effects & Yes & Yes & No & No \\
\hline$N$ & 22,317 & 22,317 & 22,317 & 22,317 \\
\hline$N$ cluster & 1,146 & 1,146 & 53 & 53 \\
\hline
\end{tabular}


Table 6:

\section{Separating the Merger Effect from the Competition Effect}

Panel A reports results from regressions of the actual change in bank loan concentration, loan rate, loan size, and future change in crime risk on the predicted change in local banking competitiveness measured through mergers between non-failing banks and bank holding companies with at least $\$ 1$ billion in assets, $\Delta$ BankHI $_{y r_{1}: y r_{2}}$, and a dummy variable for the presence of a merger. The former variable captures the predicted competitive effects of mergers and the latter captures the effect of the merger per se, irrespective of its competitive effects. Panel B repeats the regressions on the merger dummy variable alone for only those properties residing in an area where mergers have no predicted effect on competition (i.e., where the continuous measure $\left.\Delta B a n k H I_{y r_{1}: y r_{2}}=0\right)$. All regressions include a constant and all of the control variables from Tables 2 and 4, including property type and county fixed effects as well as year and bank fixed effects for the loan term regressions. Coefficient estimates and their associated $t$-statistics (in parentheses) are reported with robust standard errors that assume group-wise clustering at the zip code level.

\section{Panel A: All property transactions}

\begin{tabular}{|c|c|c|c|c|}
\hline \multirow[b]{4}{*}{ Dependent variable $=$} & \multirow{4}{*}{$\begin{array}{c}(1) \\
\text { Loan } \\
\text { rate }\end{array}$} & \multirow{4}{*}{$\begin{array}{c}(2) \\
\text { Loan } \\
\text { size }\end{array}$} & \multicolumn{2}{|c|}{ Changes in future crime } \\
\hline & & & $(3)$ & $(4)$ \\
\hline & & & \multicolumn{2}{|c|}{$\% \Delta$ Crime $_{1995: 2000}$} \\
\hline & & & Burglary & Property \\
\hline$\Delta$ BankHI $_{1992: 1995}$ & & & $\begin{array}{l}0.3825 \\
(2.29)\end{array}$ & $\begin{array}{c}0.3991 \\
(2.49)\end{array}$ \\
\hline$\Delta$ BankHI $I_{1992: \text { saleyear }}$ & $\begin{array}{c}22.2663 \\
(2.76)\end{array}$ & $\begin{array}{c}-1.3444 \\
(-1.76)\end{array}$ & & \\
\hline Merger dummy & $\begin{array}{c}-0.0588 \\
(-1.12)\end{array}$ & $\begin{array}{c}0.0168 \\
(2.82)\end{array}$ & $\begin{array}{c}-0.0003 \\
(-0.27)\end{array}$ & $\begin{array}{c}0.0013 \\
(1.38)\end{array}$ \\
\hline Fixed effects: & & & & \\
\hline Year & Yes & Yes & No & No \\
\hline Property type & Yes & Yes & Yes & Yes \\
\hline County & Yes & Yes & Yes & Yes \\
\hline Bank & Yes & Yes & No & No \\
\hline Adj. $R^{2}$ & 0.28 & 0.03 & 0.87 & 0.86 \\
\hline$N$ & 6,267 & 11,809 & 22,317 & 22,317 \\
\hline$N$ cluster & 915 & 1,100 & 1,146 & 1,146 \\
\hline
\end{tabular}

Panel B: Mergers with no predicted competitive effects, $\triangle B a n k H I=0$

\begin{tabular}{|c|c|c|c|c|}
\hline \multirow[b]{4}{*}{ Dependent variable $=$} & \multirow{4}{*}{$\begin{array}{c}(1) \\
\text { Loan } \\
\text { rate }\end{array}$} & \multirow{4}{*}{$\begin{array}{c}(2) \\
\text { Loan } \\
\text { size }\end{array}$} & \multicolumn{2}{|c|}{ Changes in future crime } \\
\hline & & & $(3)$ & (4) \\
\hline & & & \multicolumn{2}{|c|}{$\% \Delta$ Crime $_{1995: 2000}$} \\
\hline & & & Burglary & Property \\
\hline \multirow[t]{2}{*}{ Merger dummy } & 0.0552 & 0.0278 & 0.0001 & 0.0001 \\
\hline & $(0.47)$ & $(8.72)$ & $(0.09)$ & $(0.10)$ \\
\hline \multicolumn{5}{|l|}{ Fixed effects: } \\
\hline Year & Yes & Yes & No & No \\
\hline Property type & Yes & Yes & Yes & Yes \\
\hline County & Yes & Yes & Yes & Yes \\
\hline Bank & Yes & Yes & No & No \\
\hline Adj. $R^{2}$ & 0.34 & 0.03 & 0.84 & 0.78 \\
\hline$N$ & 3,593 & 5,958 & 14,544 & 14,544 \\
\hline$N$ cluster & 580 & 688 & 801 & 801 \\
\hline
\end{tabular}




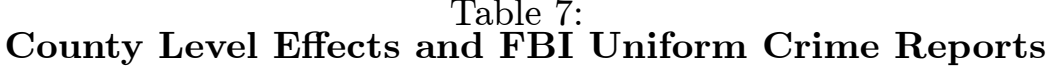

County level regressions of changes in future real activity and crime on predicted changes in local bank competition through bank mergers of non-failing commercial bank and bank holding companies with at least $\$ 1$ billion in assets are reported. Panel A reports results for construction and business activity and Panel B for crime rates from the FBI's Uniform Crime Reports. The dependent variables in the first two columns of Panel A are the county level changes from 1995 to 2000 in number of construction employees and companies, obtained from the Bureau of Labor Statistics and Bureau of Economic Analysis County Business Patterns. The last two columns of Panel A employ county level changes from 1995 to 2000 in total value of new construction $(\$ 1,000)$ and number of new units constructed as dependent variables, obtained from F.W. Dodge Division of the McGraw-Hill Companies, Inc. The dependent variables in Panel B are county level changes from 1995 to 2000 in reported homicides and burglaries per capita. All regressions include a constant, the current crime rate (1995), recent growth in crime (from 1990 to 1995), local price variation, recent growth in population, income, and home value (from the 1990 to 2000 Census), and state fixed effects. In addition, for the crime rate regressions results are reported employing the average abortion rate from 1982 to 1986 for the state in which the property resides and the log of the average state imprisonment rate (number of prisoners per capita) from 1994 to 1995. Coefficient estimates and their associated $t$-statistics (in parentheses) are reported with robust standard errors that assume group-wise clustering at the county level.

\begin{tabular}{|c|c|c|c|c|}
\hline \multicolumn{5}{|c|}{ Panel A: County level new construction activity } \\
\hline \multirow{3}{*}{ Dependent Variable $=$} & $(1)$ & $(2)$ & $(3)$ & (4) \\
\hline & \multicolumn{2}{|c|}{$\Delta$ Number of Construction } & \multicolumn{2}{|c|}{$\Delta$ New Construction } \\
\hline & Employees & Companies & Value & Units \\
\hline$\Delta$ BankH $I_{1992: 1995}$ & $\begin{array}{c}-18.6751 \\
(-5.09)\end{array}$ & $\begin{array}{c}-0.7493 \\
(-4.54)\end{array}$ & $\begin{array}{c}-6.3611 \\
(-7.29)\end{array}$ & $\begin{array}{l}-6.4089 \\
(-11.97)\end{array}$ \\
\hline State fixed effects & Yes & Yes & Yes & Yes \\
\hline Adj. $R^{2}$ & 0.41 & 0.69 & 0.09 & 0.63 \\
\hline$N$ & 21,940 & 21,940 & 21,968 & 21,968 \\
\hline$N$ cluster & 38 & 38 & 41 & 41 \\
\hline \multicolumn{5}{|c|}{ Panel B: County Level Crime Rates from the FBI Uniform Crime Reports } \\
\hline & (1) & $(2)$ & $(3)$ & $(4)$ \\
\hline & \multicolumn{4}{|c|}{ Changes in crime rate from 1995 to 2000} \\
\hline Dependent Variable $=$ & Burglary & Homicide & Burglary & Homicide \\
\hline$\Delta$ BankH $I_{1992: 1995}$ & $\begin{array}{l}2.5076 \\
(4.08)\end{array}$ & $\begin{array}{c}-2.2819 \\
(-0.70)\end{array}$ & $\begin{array}{l}5.5948 \\
(2.16)\end{array}$ & $\begin{array}{l}0.6431 \\
(0.12)\end{array}$ \\
\hline Abortion rate $1982: 1986$ & & & $\begin{array}{l}-1.0510 \\
(-5.05)\end{array}$ & $\begin{array}{c}-0.5596 \\
(-2.12)\end{array}$ \\
\hline $\log (\text { imprisonment rate) })_{1994: 1995}$ & & & $\begin{array}{l}0.2838 \\
(2.44)\end{array}$ & $\begin{array}{c}0.2175 \\
(1.73)\end{array}$ \\
\hline State fixed effects & Yes & Yes & No & No \\
\hline Adj. $R^{2}$ & 0.97 & 0.92 & 0.62 & 0.30 \\
\hline$N$ & 21,958 & 21,461 & 21,958 & 21,461 \\
\hline$N$ cluster & 39 & 38 & 39 & 38 \\
\hline
\end{tabular}




\section{Table 8: \\ The Impact of State-Level Bank Branching Regulation on Bank Concentration, Loan Activity, Prices, and Crime}

Panel A employs commercial property transaction level data from COMPS from 1992 to 1999. Regressions of the level of local bank concentration, loan rate, loan size, and capitalization rate of properties on the number of years since the state first allowed unrestricted branching (takes on the value zero if the state had yet to institute unrestricted branching at the time of the property sale) are reported. Regressions include a constant, current crime risk (1995), recent growth in crime (from 1990 to 1995), recent growth in population, income, and home value, and property type fixed effects. Loan rate regressions also include the loan attributes from Table 2. Coefficient estimates and their associated $t$-statistics (in parentheses) are reported with robust standard errors that assume group-wise clustering at the state and year level. Panel B employs state-level data on crime rates (reported homicides and burglaries per 1,000 people) from the FBI's Uniform Crime Reports from 1978 to 2001. The year-to-year percentage changes in crime rates are regressed on a state level bank branching indicator which takes on the value one if the state had adopted unrestricted branching within the last five years. Regressions also include a constant, the one year lagged change in state population, employment, social services (the number of social service employees per capita), income, and imprisonment rate (number of prisoners per capita), as well as the 16 year lagged change in the state abortion rate $(\times 1,000)$, which is the change in the number of abortions (16 years ago) per 1,000 live births. Cross-sectional regressions across all 50 states plus the District of Columbia are run each year from 1978 to 2001 (1987 to 2001 when including abortion rates) in the style of Fama and MacBeth (1973), where the time-series average of the yearly cross-sectional regression coefficient estimates are reported along with their time-series $t$-statistics (in parentheses).

\begin{tabular}{|c|c|c|c|c|}
\hline \multicolumn{5}{|c|}{ Panel A: Transaction level loan activity and prices from COMPS } \\
\hline \multirow{3}{*}{ Dependent Variable $=$} & (1) & $(2)$ & (3) & (4) \\
\hline & Actual & Loan rate & Loan size & Cap rate \\
\hline & BankHI & & & $(\mathrm{E} / \mathrm{P})$ \\
\hline \multirow[t]{2}{*}{ Years of Unrestricted Branching } & -0.0006 & -0.0152 & 0.0015 & -0.0230 \\
\hline & $(-3.19)$ & $(-2.02)$ & $(4.25)$ & $(-3.37)$ \\
\hline \multirow[t]{2}{*}{ Price Variation } & -0.0074 & 0.0410 & -0.0147 & 0.6660 \\
\hline & $(-2.24)$ & $(0.36)$ & $(-1.46)$ & $(5.97)$ \\
\hline \multirow[t]{2}{*}{ Population Growth } & 0.0002 & 0.0051 & -0.0003 & -0.0059 \\
\hline & $(1.78)$ & $(0.46)$ & $(-0.35)$ & $(-0.69)$ \\
\hline \multirow[t]{2}{*}{ Income Growth } & 0.0012 & 0.1401 & -0.0001 & -0.0499 \\
\hline & $(2.72)$ & $(1.34)$ & $(-0.66)$ & $(-0.40)$ \\
\hline \multirow[t]{2}{*}{ Home Value Growth } & 0.0001 & -0.0003 & -0.0001 & \\
\hline & $(2.20)$ & $(-0.39)$ & $(-2.11)$ & \\
\hline$N$ & 22,317 & 6,267 & 16,131 & 10,070 \\
\hline$N$ cluster & 96 & 96 & 96 & 96 \\
\hline \multicolumn{5}{|c|}{ Panel B: State level changes in crime across all 50 states from the FBI } \\
\hline & \multicolumn{4}{|c|}{ Fama-MacBeth Cross-Sectional Regressions } \\
\hline & $(1)$ & $(2)$ & $(3)$ & $(4)$ \\
\hline $\begin{array}{l}\text { Dependent Variable }=\% \Delta \text { Crime }_{t} \\
\text { per } 1,000 \text { People }\end{array}$ & $\begin{array}{c}\% \Delta \text { Homicide }_{t} \\
(1978-2001)\end{array}$ & $\begin{array}{c}\% \Delta \text { Homicide }_{t} \\
(1987-2001)\end{array}$ & $\begin{array}{c}\% \Delta \text { Burglary } t \\
(1978-2001)\end{array}$ & $\begin{array}{c}\% \Delta \text { Burglary }_{t} \\
(1987-2001)\end{array}$ \\
\hline \multirow[t]{2}{*}{ Post Unrestricted Branching Indicator } & -0.0094 & -0.0143 & -0.0150 & -0.0100 \\
\hline & $(-0.87)$ & $(-1.39)$ & $(-3.48)$ & $(-3.40)$ \\
\hline \multirow[t]{2}{*}{$\Delta$ Population $_{t-1}$} & -0.0001 & 0.0001 & -0.0001 & -0.0001 \\
\hline & $(-0.53)$ & $(0.49)$ & $(-0.48)$ & $(-1.08)$ \\
\hline \multirow[t]{2}{*}{$\Delta$ Employment $_{t-1}$} & 5.5718 & 4.8934 & 0.7494 & 0.5595 \\
\hline & $(5.03)$ & $(5.39)$ & $(2.71)$ & $(2.12)$ \\
\hline \multirow[t]{2}{*}{$\Delta$ Social Services $_{t-1}$} & -0.0070 & -0.0056 & -0.0029 & -0.0042 \\
\hline & $(-4.21)$ & $(-5.72)$ & $(-6.25)$ & $(-9.36)$ \\
\hline \multirow[t]{2}{*}{$\Delta$ Income $_{t-1}$} & -23.981 & -14.509 & -3.4942 & 2.8806 \\
\hline & $(-3.31)$ & $(-2.48)$ & $(-1.70)$ & $(2.32)$ \\
\hline \multirow[t]{2}{*}{$\Delta{\text { Imprisonment } \text { Rate }_{t-1}}$} & -0.0261 & -0.0106 & 0.0129 & 0.0088 \\
\hline & $(-1.29)$ & $(-1.09)$ & $(2.68)$ & $(2.35)$ \\
\hline \multirow[t]{2}{*}{$\Delta$ Abortion Rate $_{t-16}$} & & -0.3173 & & -0.1007 \\
\hline & & $(-5.75)$ & & $(-6.08)$ \\
\hline$N($ \# years $)$ & 24 & 15 & 24 & 15 \\
\hline
\end{tabular}


Figure 1. Distribution of Predicted Change in Bank Concentration from Mergers of Non-failing Commercial Bank and Bank Holding Companies with Assets Greater than $\$ 1$ Billion

The distribution of the predicted change in banking competitiveness measures through mergers of non-failing commercial bank and bank holding companies with at least $\$ 1$ billion in assets are plotted. The predicted change in banking competitiveness from year $y r_{1}$ to $y r_{2}$ caused by mergers, $\triangle B a n k H I_{y r_{1}: y r_{2}}$, is defined as the sum of the individual year increases in the Herfindahl concentration index, $\Delta B a n k H I_{y r_{1}: y r_{2}, j}=\sum_{y r=y r_{1}}^{y r_{2}}\left(B a n k H I_{j, y r}^{\text {merge }}-B a n k H I_{j, y r}^{a c t u a l}\right)$, where BankHI $I_{j, y r}^{a c t u a l}$ is the actual Herfindahl concentration index of commercial real estate bank loans within 15 miles of property $j$ (excluding $j$ itself) and $B a n k H I_{j, y r}^{\text {merge }}$ is the hypothetical concentration index assuming all non-failing commercial bank mergers took place at the

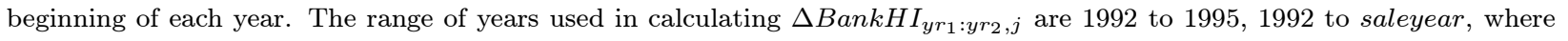
saleyear is the year in which the property transacted, and 1992 to 1999 . The distribution and summary statistics for the entire sample and only those where the predicted change in concentration is positive are reported.
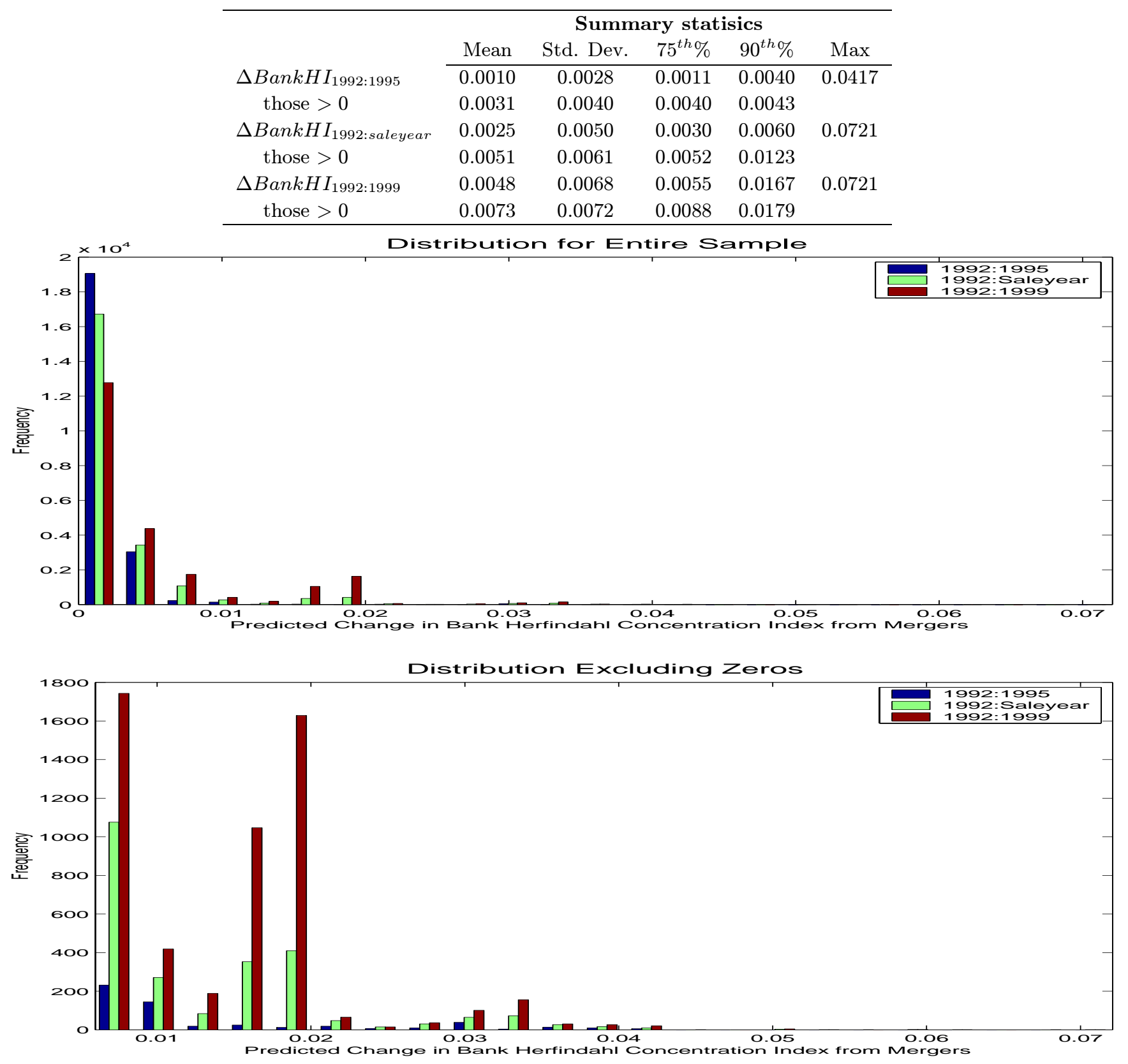